Research Report No. 16/2011

\title{
The Evolution of General Administrative Law and the Emergence of Postmodern Administrative Law
}

Karl-Heinz Ladeur

Follow this and additional works at: http:/ / digitalcommons.osgoode.yorku.ca/clpe

\section{Recommended Citation}

Ladeur, Karl-Heinz, "The Evolution of General Administrative Law and the Emergence of Postmodern Administrative Law" (2011). Comparative Research in Law \& Political Economy. Research Paper No. 16/2011.

http://digitalcommons.osgoode.yorku.ca/clpe/54 


\section{OSGOODE}

OSCOODE HALL LAW SCHOOL

YOR K UNIVERSITY

\section{OSGOODE HALL LAW SCHOOL}

Comparative Research in Law \& Political Economy

RESEARCH PAPER SERIES

Research Paper No. 16/2011

\section{The Evolution of General Administrative Law and the Emergence of Postmodern Administrative Law}

Karl-Heinz Ladeur

\section{Editors:}

Peer Zumbansen (Osgoode Hall Law School, Toronto, Director, Comparative Research in Law and Political Economy)

John W. Cioffi (University of California at Riverside)

Lisa Philipps (Osgoode Hall Law School, Associate Dean Research)

Nassim Nasser (Osgoode Hall Law School, Toronto,

Production Editor) 
Osgoode CLPE Research Paper 16/2011

Vol. 07 No. 04 (2011)

Karl-Heinz Ladeur

\title{
The Evolution of General Administrative Law and the Emergence of Postmodern Administrative Law
}

\begin{abstract}
The discussion on the emergence of global administrative law is centered around the question: "Is it law?" and problems of accountability. This is a narrow perspective which ignores the autonomy of the administrative "internal law" generated by administrative agencies themselves. This is shown for the evolution of domestic administrative law in the $19^{\text {th }}$ century and its transformations in the $20^{\text {th }}$ century. Domestic administrative law is only to a much lesser extent a product of courts or legislators than hitherto taken for granted. This is why it should not come as a surprise that the instruments and forms of global administrative law are generated by transnational administrative networks of agencies. The evolution of both domestic and transnational administrative law will allow for new heterarchical forms of accountability and legitimation once the focus on a hierarchical concept of delegation is given up. The paper tries to outline a perspective on the transformation of administrative law based on domestic administrative law but at the same time intends to open a perspective on a new look at the emergent global administrative law.
\end{abstract}

Keywords: accountability, global administrative law, autonomy, administrative "internal law", Domestic administrative law, transnational administrative networks of agencies, new heterarchical forms of accountability, legitimation, delegation, transformation

JEL Classification: K 39

\author{
Karl-Heinz Ladeur \\ Professor emeritus of public law, \\ University of Hamburg \\ Distinguished Bremen Professor, \\ Bremen International Graduate School of Social Sciences
}




\title{
The Evolution of General Administrative Law and the Emergence of Postmodern Administrative Law
}

\author{
Karl-Heinz Ladeur ${ }^{*}$
}

\section{Preliminary Remarks}

The discussion on "international administrative law" has been established - following the logic of its object - as an international topic for quite some time. However, this evolution does not exclude the differentiation of, so to speak, regional and methodologically approaches within the global network of legal research: in the US, one can observe a focus on "global administrative law" at the law faculty of NYU - and this shift of the accent to "global" instead of "international administrative law" is not without consequences. The focus is more on case studies and methodological questions. ${ }^{1}$ This approach corresponds with the ideas of an Italian group of researchers, which has been set up at Viterbo, ${ }^{2}$ and with other individual contributors to the international discussion. In as far as one can already talk about an established field of research in Germany, one can observe a different focus on a rather traditional systematic differentiation of certain "matters" which are undergoing a process of internationalisation. ${ }^{3}$ In the following, an approach will be developed which tries to build a bridge between global and domestic administrative law. It will be shown that there is a close link between the evolution of administrative law in postmodernity and the emergence of global administrative law, and that the basic institutions of administrative law are products of the autonomous rationality of administration. This sheds new light on the questions of both the accountability and the legitimation of transnational global networks.

\footnotetext{
* The author is professor emeritus of public law at the University of Hamburg, as of 2008 he is Distinguished Bremen Professor at the Bremen International Graduate School of Social Sciences, Bremen (Germany); from 1994 to 2002 he was professor at the law department of the European University Institute, Florence (Italy). Email: KarlHeinz Ladeur <karl-heinz.ladeur@jura.uni-hamburg.de>

${ }^{1}$ See Benedict Kingsbury, Nico Krisch \& Richard B. Stewart, The Emergence of Global Administrative Law, (68 LAW AND CONTEMPORARY PROBLEMS, 15 (2005); Carol Harlow, Global Administrative Law: The Quest for Principles and Values", 17 EUROPEAN JOURNAL OF INTERNATIONAL LAW, 187 (2006); Jean-Bernard Auby, LA GLOBALISATION. LE DROIT ET L'ETAT, 2nd ed., 2010.

${ }^{2}$ www.ricercaitaliana.it/prin/unita

${ }^{3}$ See the contributions in: INTERNATIONALES VERWALTUNGSRECHT (Christoph Möllers \& Andreas Voßkuhle, eds) 2007).
} 


\section{The Autopoiesis Of LAW AND the EMERgenCE Of Global AdMinistrative LAW}

\section{A. No Administrative Law Beyond Delegation of Power? The Self-Generative Function of AdMINISTRATIVE LAW IN THE EVOLUTIONARY PROCESS}

In systems theory, the focus of the observation of the legal system shifts from norms to decision-making, i.e., the legal system is regarded as being composed of decisions, not of persons and not of norms as the object of application to specific cases. At least, this is constitutive of the difference between centre (decisions) and periphery (legislation) of the legal system. This may sound counter-intuitive to traditional approaches to law, and it may not do sufficient justice to the practice of contracting ${ }^{4}$ and other transactions, which do not take on the form of a binding decision. ${ }^{5}$ However, this discussion will not be taken up here. The autopoietic construction of the legal system as processing from decision to decision is opposed to a more traditional conception of decision-making as deriving (specific) decisions for cases from a (general) norm which is integrated in a whole system of legal rules and - super-imposed at this level of norms - a set of principles which integrate the law in a system. For the purposes of this article, the difference between continental European and Anglo-American law will be left aside, because, as will be shown later, the blind spot of the most diffused approaches to the understanding of the self-transformation of the legal system that the law undergoes under the pressure of the evolution of modern society is the same in both traditions. The focus of the following assumption is more on the inevitable autonomy of not only judicial, but also administrative, decision-making, which allows for a recognition of the creative normative function of the processing of administrative decision-making. ${ }^{6}$ The traditional conception tends to reduce the creative norm-generating role beyond the legislative authority to the judiciary whereas the this normative role of the administration is left in the shadow. Modern

\footnotetext{
${ }^{4}$ See Jody Freeman, Collaborative Governance in the Contracting State, 45 UNIVERSITY OF LOS ANGELES LAW REVIEW, 1 (1998); ead., The Contracting State, 28 FLORIDA STATE UNIVERSITY LAW REVIEW, 155 (2001), (arguing that the rise of the contract in administrative action is a sign of a general transformation towards a more open type of "governance" and not a symptom of decline of democratic legitimation of administrative agencies); Alfred A. Aman jr., Globalization, and the Need for a New Administrative Law, 49 UNIVERSITY OF LOS ANGELES LAW REVIEW, p. 1687 (2002); for a critique, see Mark Seidenfeld, An Apology for Administrative Law in the "Contracting State", 28 FLORIDA STATE UNIVERSITY LAW REVIEW, 215 (2001), (emphasising the flexibility that was already inherent in traditional administrative law); for the far advanced practices of the contracting state in the UK, see Peter Vincent-Jones, THE NEW CONTRACTING STATE: REGULATION, RESPONSIVENESS, RELATIONALITY (Oxford: Oxford University Press, 2006).

${ }^{5}$ See in a theoretical perspective Karl-Heinz Ladeur, Das subjektive Recht als Medium der Selbstransformation des Rechts and Gerechtigkeit als deren Parasit, p. 109 \& 114 et seq., in: ZUR (UN-) MÖGLICHKEIT EINER GESELLSCHAFTSTHEORIE DER GERECHTIGKEIT (Gunther Teubner, ed., 2008).

6 Jerry L. Mashaw, Reluctant Nationalists: Federal Administration and Administrative Law in the Republican Era 1801-1829,116 YALE LAW REVIEW 1636 (2007).
} 
administrative law cannot, of course, deny a creative element that is termed "discretion", although this leeway for administrative autonomy is hidden within the idea of a legislative delegation of power. ${ }^{7}$

"Delegation" includes the assumption that the domain of options within which the "delegated" power of administrative decision-makers can develop is defined by the legislator. However, global administrative law is confronted with the design of forms, instruments and procedures beyond the established rules of general administrative law and its inherent structuring function. ${ }^{8}$ As will be shown in more detail below, the fundamental forms and components of general administrative law have not been developed by the legislator nor by the judiciary (which has made some of its implicit rules explicit), but by an experimental search process of the administration itself. ${ }^{9}$ The ensuing "reverse" process of norm-generation - from administrative experimental rule generation to explicit stabilisation through courts and finally through legislation - appears to be incompatible with the traditional understanding of the separation of powers.

This unavoidable self-generative element of the legal system is due to the fact that we have to distinguish- from explicit rule-making - an evolutionary process of self-transformation of (not only administrative) law, which is due to the dynamic of society at large, including its knowledge basis and the social norms and expectations that try to cope with the societal complexity. As will be discussed later, the basic forms of both administrative and private law are not created by the legislator, but are, instead, stabilised ex post by the formulation of historical "versions" in the legislative process which correspond to a societal challenge which is managed - in a first step - by administrative or judicial decision-makers (the latter in private law).

\footnotetext{
${ }^{7}$ See only the overview in Francesca Bignami, The Administrative State in a Separation of Powers Constitution: Lessons for European Community Rule-Making from the United States, Jean Monnet Center for International and Regional Economic Law and Justice, New York University, 1999; for a critique see Jerry L. Mashaw, Federal Administration and Administrative Law of the Gilded Age, 119 YALE LAW JOURNAL 1362, 1377 et seq. (2010).

${ }^{8}$ See Eberhard Schmidt-Aßmann, DAS ALLGEMEINE VERWALTUNGSRECHT ALS ORDNUNGSIDEE (2d ed., 2004).

${ }^{9}$ The role of courts in the development of general administrative law is overstated when the latter is reduced to judge-made law, see Benedict Kingsbury, The Concept of 'Law' in Global Administrative Law, 20 EUROPEAN JOURNAL OF INTERNATIONAL LAW23 (2009): from the absence of a legislative delegation of power to administrative deciders does not follow a supplementary norm generating role of courts alone, administration itself has to be regarded as the creator of the instruments and forms of administrative law; the role of the judges consisted rather in the doctrinal stabilisation of the institutions of general administrative law, for the role of doctrine in general administrative law see Eberhard Schmidt-Aßmann, ALLGEMEINES VERWALTUNGSRECHT ALS ORDNUNGSIDEE ( $2^{\text {nd }}$ ed., 2006) 3 et seq. and Jens Kersten \& Sophie-Charlotte Lenski, Die Entwicklungsfunktion des Allgemeinen Verwaltungsrechts, 42 DIE VERWALTUNG 503 (2009); Oliver Lepsius, Themen der Rechtswissenschaftstheorie, 1, 27, in:, RECHTSWISSENSCHAFTSTHEORIE (Matthias Jestaedt \& id. , eds., 2008) . For a critique of simplistic "functionalist" conception of legislation as the (generative) democratic will see Martin Loughlin, PUBLIC LAW AND POLITICAL THEORY 60 (2003); id., WHAT IS PUBLIC LAW?, 151 et seq. (2003).
} 
Neither administrative nor private law can be understood and practiced without the observation of social norms and cognitive assumptions of normality. The legal system is linked permanently to the "collective knowledge" of society ${ }^{10}$ and the basic forms of attribution of responsibility: in modernity, we can first observe the emergence of the "society of individuals", ${ }^{11}$ which provokes the rise of a new administrative law based upon individual decisions. The next stage of the evolution of administrative law is characterised by the new paradigms derived from the requirements of the "society of organisations" and its consequences (such as planning law, the forms of the welfare state, etc.) The forms and procedures of this new stage of administrative law had to be found in an experimental process first, and could afterwards be integrated in new types of laws and legal procedures of decisionmaking. We are now confronted with a new change of paradigm, the rise of the "network society", which, again, demands new administrative forms and procedures for decision-making in conditions of increasing complexity. With Jerry L. Mashaw, one might describe the evolution of administrative law as underlying a "cyclical oscillation between categorical and contextual norms". ${ }^{12}$ Administrative law is deeply characterised by paradigmatic transformations which are initiated by administrative decision-makers in experimental processes and finally stabilised by court practice and the legislator.

The hypothesis which underlies the following reflections is based upon the assumption that the globalisation process does not invade a stable domestic administrative (or private) legal system from outside, but that it is also a consequence of an evolutionary process that disrupts the legal system from within. It goes without saying that this evolutionary model does not assume that the new paradigms replace the older ones completely ${ }^{13}$, but that we have to conceive of the legal system of postmodernity as being multi-layered because the new paradigms are based upon a secondary respectively tertiary re-modelling of the preceding one. This hypothesis can explain the unavoidable and legitimate creative role of administrative agencies in the new transnational realm of decision-making, and allows for a more systematic self-reflection of the dynamic process of change in administrative and private law.

\footnotetext{
${ }^{10}$ One can even speak about the "fact" in legal contexts as not being a "truth" but the product of a legal procedure, Barbara J. Shapiro, A CULTURE OF FACT. ENGLAND, 1550 - 1720, 11 (2000).

${ }^{11}$ Norbert Elias, THE SOCIETY OF INDIVIDUALS(1939 in German, 1991).

12 Jerry L. Mashaw, Accountability and Intellectual Design: Some Thoughts on the Grammar of Governance, 115, 154 et seq., in: PUBLIC ACCOUNTABILITY: DESIGNS, DILEMMAS, EXPERIENCES (Michael Dowdle, ed., 2006).

${ }^{13}$ This is why the question posed by Carolyn J. Hill \& Laurence E. Lynn, Is Hierarchical Governance in Decline? Evidence from Empirical Research, 15 JOURNAL OF PUBLIC ADMINISTRATION. RESEARCH AND THEORY ( 2005) 173, 189 , is legitimate though the authors' quantitative focus on the permanence of hierarchical structures of decision making is only of limited analytical value.
} 


\section{B. A Side Look at Private LaW: Is Lex Mercatoria LaW?}

Some legal theorists have put forward the claim that global law, the Lex Mercatoria as a selforganised practice of private law, in particular, has to be regarded as "less closed" and less autonomous. ${ }^{14}$ However, this would be a misunderstanding: as will be shown later, global law differs considerably from state-based law; this notwithstanding, the law should not be regarded as losing its autonomy under conditions of globalisation. Instead, the network paradigm can contribute to a better understanding of the new types of transnational legal practices: Lex Mercatoria lacks the coherence and methodological foundation of traditional private law, ${ }^{15}$ but this is not a problem, because the common frame of interests of (mainly) big transnational firms can compensate for the lack of guidance of the arbitration practices. Its openness is further attenuated by the practice of referring to clusters of arbitration decisions and the UNIDROIT-principles. ${ }^{16}$ A parallel might be drawn between this new type of entanglement of norms and contracts in private law, and the new creative function of administrative agencies, which consists of the design of new forms of action in transnational networks of public and private actors.

The disruptions and fragmentations emerging from the evolution of the "global law beyond a state $^{17}$ or, rather, from a heterarchical "network of networks" of law with varying combinations of characteristics according to actors, transactions, knowledge bases do not according to systems theory - call into question the autonomy of law as a self-constructing system which operates with its own tool box and observes itself within its own horizon, which

\footnotetext{
${ }^{14}$ Assuming only a "relative autonomy" and reducing the law finally to what the judge say what the law is: Michel van de Kerchove und François Ost, LE DROIT OU LES PARADOXES DU JEU (1992); for an alternative position see G. Teubner, Breaking Frames: The Global Interplay of Legal and Social Systems, 45 THE AMERICAN JOURNAL OF COMPARATIVE LAW 149 (1997), id. \& Peter Korth, Zwei Arten des Rechtspluralismus: Normkollisionen in der doppelten Fragmentierung der Weltgesellschaft, 137 in: NORMATIVE PLURALITÄT ORDNEN (Mattias Kötter \& Gunnar Folke Schuppert, eds., 2009); from a political science perspective Alec Stone Sweet, The New Lex Mercatoria and Transnational Governance, 13 JOURNAL OF EUROPEAN PUBLIC POLICY 627 (2006).

${ }^{15}$ Wolfgang Peter, Jean-Quentin de Kuyper \& Benedict de Candolle, ARBITRATION AND RENEGOTIATION OF INTERNATIONAL INVESTMENT AGREEMENTS 152 (1995); Paul Lagarde, Approche critique de la Lex Mercatoria, in: ETUDES OFFERTES À BERTHOLD GOLDMANN 125, 133 (1983); Andreas Abegg, From the Social Contract to a Social Contract Law. Forms an Functions of Administrative Contracts in a Fragmented Society: A Continental View, Center for the Study of Law and Society Faculty Working Paper, February 2008.

${ }^{16}$ Axel Metzger, EXTRA LEGEM, INTRA IUS. ALLGEMEINE RECHTSGRUNDSÄTZE IM EUROPÄISCHEN PRIVATRECHT 533 (2009); Ursula Stein, LEX MERCATORIA 242 (1995); for the evolution of its self-reflexive momentum see also Gunther Teubner,"Global Bukowina". Legal Pluralism in the World Society, in: GLOBAL LAW WITHOUT A STATE, 12 (1997); Andreas Fischer-Lescano \& id., Regime Collision The Vain Search for Legal Unity in the Fragmentation of Global Law, 25 MICHIGAN JOURNAL OF INTERNATIONAL LAW 999 (2004); Peer Zumbansen, Piercing the Legal Veil: Commercial Arbitration and Transnational Law, 8 EUROPEAN LAW JOURNAL 400 (2002); Gralf-Peter Calliess \& M. Renner, From Soft Law to Hard Code: The juridification of Global Governance, SSRN-WP 2007; Andreas FischerLescano, Transnationales Verwaltungsrecht, 63 JURISTENZEITUNG 373 (2008); see also the contributions in: INTERNATIONALES VERWALTUNGSRECHT (Christoph Möllers, Andreas Voßkuhle \& Christian Walter, eds., 2007).

${ }^{17}$ See Gunther Teubner, Breaking Frames: Economic Globalization and the Emergence of Lex Mercatoria, 5 EUROPEAN JOURNAL OF SOCIAL THEORY 199 (2002).
} 
cannot but draw a distinction between itself and its environment (the other systems in particular) and is not just driven by external forces (like the political or the economic system). ${ }^{18}$

However, it is not without consequence that it is not just from the point of view of systems theory that the question "is global law "law'?" has to be raised. ${ }^{19}$ The doubt that the question may be answered in the negative is one of the uncertainties which irritate the professional observers of the practices that are termed "global law" as opposed to international law. ${ }^{20}$ This is probably one of the reasons why N. Luhmann took the view that the "world society" ${ }^{21}$ beyond the legally-structured nation state and the international public law as centred on the nation state as well - is increasingly governed by "cognitive" rules, ${ }^{22}$ and not in any traditional normative mode.

\section{GLOBAL LAW - IS IT LAW?}

In the present discussion on global law, the question "Is it law?" has been raised in particular by G. Teubner, ${ }^{23}$ and, recently, by $\mathrm{B}$. Kingsbury. ${ }^{24}$ The recognition of a possible "generation of

${ }^{18}$ Kingsbury, supra, note 9; David Dyzenhaus, The Concept of (Global) Administrative Law', IIL Working Paper 2008/7, www.iili.org; for lex mercatoria Teubner , supra, note 17 ; id \& Korth, supra, note 14.

${ }^{19}$ Kingsbury, supra, note 9; see also Alec Stone Sweet \& Florian Grisel, L'arbitrage international: Du contrat dyadique au système normatif, 52 ARCHIVES DE PHILOSOPHIE DE DROIT 75 (2009) who focus on the judge-like stabilisation of a "dyadic" normative practice by a third party; this view underestimates the autonomous creative potential of a transsubjective practice.

20 See Eberhard Schmidt-Aßmann, Die Herausforderung der Verwaltungsrechtswissenschaft durch die Internationalisierung der Verwaltungsbeziehungen, 45 DER STAAT 315 (2006); Franz C. Mayer, DIE INTERNATIONALISIERUNG DES VERWALTUNGSRECHTS (2006); Auby, supra, note 1; Stefano Battini, AMMINISTRAZIONI SENZA STATO. PROFILI DI DIRITTO AMMINISTRATIVO INTERNAZIONALE (2003); Sabino Cassese, LO SPAZIO GIURIDICO GLOBALE (2003); id., The Globalisation of Law, 37 NEW YORK UNIVERSITY JOURNAL OF INTERNATIONAL LAW AND POLITICS 976 (2006); Richard B. Stewart, The Global Regulatory Challenge to U.S. Administrative Law, 695.

${ }^{21}$ For the concept of the "world society" see Niklas Luhmann, Die Weltgesellschaft, 51, in: SOZIOLOGISCHE AUFKLÄRUNG, Vol. 2, (id., 1975).

22 David Kennedy, The Mystery of Global Governance, 37, 58, in: RULING THE WORLD? CONSTITUTIONALISM, INTERNATIONAL LAW, AND GLOBAL GOVERNANCE (Jeffrey L. Dunoff \& Joel P. Trachtman, eds., 2009).

${ }^{23}$ Gunther Teubner, Self-Constitutionalization of Transnational Corporations? On the Linkage of "Private" and "Public" Corporate Codes of Conduct, 17 INDIANA JOURNAL OF GLOBAL LEGAL STUDIES 2010, to appear; id., Constitutionalising Polycontexturality, 19 SOCIAL AND LEGAL STUDIES 2010, to appear; id., The Corporate Codes of Multinationals: Company Constitutions Beyond Corporate Governance and Co-Determination, 203, in: CONFLICT OF LAWS AND LAWS OF CONFLICT IN EUROPE AND BEYOND (Rainer Nickel, ed., 2010); see also id., supra, note 10, 3; see also Jean-Marie Guéhenno, THE END OF THE NATION STATE (1995), 100.

${ }^{24}$ Kingsbury, supra, note 9; for a critique see Ming-Sung Kuo, Inter-Public Legality or Post-Public-Legitimacy?, A Response to Professor Kingsbury's Conception of Global Administrative Law, 20 EJIL 997 (2009; see also Ralf Michaels \& Nils Jansen, Private Law Beyond the State? Europeanization, Globalization, Privatization, 55 AMERICAN 
norms as a spontaneous process" between equal private actors seems to be quite acceptable for traditional approaches to law. ${ }^{25}$ However, this is different with reference to public law, which seems to be based upon the will of an institutionalised legislator or a delegation of lawmaking power. ${ }^{26}$ Some authors even go so far as to deny any evolutionary dimension of public law that is said to be "intentionally steered". ${ }^{27}$ Traditional public law still draws on the forms that have emerged in the realm of the nation state, and tends to deny the legal character of the new phenomena of global law when it seems to transcend the borders of international law. ${ }^{28}$ The uncertainties of the new legal order which no longer fit in the forms of law, which have been moulded by, and with reference to, the state are expressed by the use of the term "soft law". ${ }^{29}$ Jerry L. Mashaw has convincingly argued that the doubts of the "lawness" of global administrative law stem from the same origin as the conventional ignorance of the generative power of administration that manifests itself in the emergence of the "internal administrative law" in the 19th century. ${ }^{30}$ In the following, it will be shown that the basic transformations domestic administrative law has undergone in the last decades can only be explained if such an evolutionary dimension of public law, which opens a new perspective also on the emergence of global administrative law, is recognised.

In international private law, the question of whether Lex Mercatoria is law is controversial, as well.. ${ }^{31}$ In global administrative law, the question can - apparently - be left open according to

JOURNAL OF COMPARATIVE LAW 843 (2007), who give an overview of the discussion and demonstrate the primarily semantic character of the controversy; Gralf-Peter Calliess \& Peer Zumbansen, ROUGH CONSENSUS AND RUNNING CODE. A THEORY OF TRANSNATIONAL LAW 79, 113 (2010), take the view that elements of domestic law that are transplanted to the transnational sphere of law undergo a "transmutation" - one may think that this is but another version of the semantic controversy.

${ }^{25}$ See Christoph Möllers, Transnational Constitutionalism Without a Public Law?, 329, in: TRANSNATIONAL GOVERNANCE AND CONSTITUTIONALISM (Christian Joerges, Inger-Johanne Sand \& Gunther Teubner, eds., 2004).

${ }^{26}$ See with reference to (domestic) standards Veeck v. Southern Building Code Congress International, 293 F3d 791, 799 ( $5^{\text {th }}$ Cir. 2002); Harm Schepel, Constituting Private Governance Regimes, 161, 162: in: Joerges et al., (eds.), ibid.

${ }^{27}$ Möllers, supra, note 25, 330, 338.

${ }^{28}$ For the sources of international law that are relevant in global administrative law See Benedict Kingsbury, Nico Krisch \& Richard B. Stewart, The Emergence of Global Administrative Law, 68 LAW AND CONTEMPORARY PROBLEMS 15, 29 (2005); for the necessity to go beyond these norms in the traditional sense see Christian Tietje, Recht ohne Rechtsquellen?, 24 ZEITSCHRIFT FÜR RECHTSSOZIOLOGIE 27, 40 (2003).

${ }^{29}$ Pierre-Marie Dupuy, Soft Law and International the Law of the Environment, 12 MICHIGAN JOURNAL OF INTERNATIONAL LAW 420 (1991); Kenneth W. Abbott \& Duncan Snidal, Strengthening International Regulation Through Transnational New Governance: Overcoming the Orchestration Deficit, 42 VANDERBILT OF TRANSNATIONAL LAW 501 (2009); for the far spread conceptual vagueness see also Anne Peters \& Lucy Koechlin, Towards Non State-Actors as Effective, Legitimate, and Accountable Standard Setters, 492, 495, in: NON-STATE ACTORS AS STANDARD SETTERS (ead, ead.,Till Förster, and Gretta Fenner Zinkernagel, eds., 2009).

${ }^{30}$ Mashaw, supra, note 6, 1470, 1476.

${ }^{31}$ See Ralf Michaels, The True Lex Mercatoria: Law Beyond the State, 14 NDIANA JOURNAL OF GLOBAL LEGAL STUDIES 447 (2007) (that lex mercatoria can neither be reduced to "anational" law nor to a derivative of state law but hat attained a new quality of a law beyond the state that combines diverse elements ); see the documentation 
many authors, because also domestic administrative practice have acknowledged a number of forms of preparation, of internal rule-making, procedures which have a strong impact on the legal processes without being (unanimously) regarded as being legal acts or legal norms in the stricter sense. ${ }^{32} \mathrm{G}$. Teubner - as a private lawyer - is focused on private legal norms, and takes the view that it is "global civil society" to which the new forms of societal legal norms can, and, indeed, have to, be attributed as an authoritative "source" of law beyond the state. This approach pre-supposes a new "societal constitutionalism" 33 that stipulates a law-making potential beyond the traditional forms of the state. ${ }^{34}$ The spontaneously generated norms of transnational operations (not only commercial in the narrower sense, but also including the "Lex Digitalis" of the global communication order or Lex Sportiva ${ }^{35}$ as the law of the transnational sports organisations and their rule-making requirements) are not generally recognised as law ${ }^{36}$ by state-based tribunals, whereas, in fact, as long as this "law" can make use of its own institutions (the international mediation procedures), it is, at least, a functional equivalent to law in the stricter sense. G. Teubner takes a more principled approach and, as a consequence of the acknowledgment of the norm-giving power of the "global civil society", attributes legal character in the stricter sense to Lex Mercatoria - following the terminology of H.L.A. Hart - because it has generated its own "secondary rules", i.e., procedures of reflection, distinction and control, as opposed to non-institutionalised norms of morality, etc. ${ }^{37}$ This reference risks to be reductionist because it sets aside the paradox of the self-generation of the law as a social practice, as a "language" with its eigenvalue, and to end up in a circular

of the controversy in Klaus-Peter Berger, FORMALISIERTE ODER "SCHLEICHENDE KODIFIIZIERUNG" DES INTERNATIONALEN WIRTSCHAFTSRECHTS (1996) (containing a differentiated discussion of all major pros and cons with reference to the question "is it law?"; see also (skeptically) Jan Kropkoller, INTERNATIONALES EINHEITSRECHT 123 (1996); more positively: Ursula Stein, LEX MERCATORIA 211 et seq. (1996); Hans-Joachim Mertens, Das Lex Mercatoria Problem, in: FESTSCHRIFT ODERSKY 857, 860 (Reinhard Böttcher et al., 1996).

32 Joel Reidenberg, Lex Informatica: The Formulation of Information Policy Rules Through Technology, 76 TEXAS LAW REVIEW 553 (1998) (describing the normative effects of technology on the legal structure of transactions via information technology). .

${ }^{33}$ David Sciulli, THEORY OF SOCIETAL CONSTITUTIONALISM: FOUNDATIONS OF A NON-MARXIST CRITICAL THEORY (1992).

${ }^{34}$ Gunther Teubner, Verfassungen ohne Staat? Zur Konstitutionalisierung transnationaler Regimes, in: RECHT OHNE STAAT (to appear, Klaus Günther \& Stefan Kadelbach, eds., 2010).

${ }^{35}$ Reidenberg, supra, note 32; Birgit Rost, DIE HERAUSBILDUNG TRANSNATIONALEN WIRTSCHAFTSRECHTS AUF DEM GEBIET DER INTERNATIONALEN FINANZ- UND KAPITALMÄRKTE 251 (2007); Christopher M. Bruner, States, Markets, and Gatekeepers: Public-Private Regulatory Regimes in an Era of Economic Globalization, 30 MICHIGAN JOURNAL OF INTERNATIONAL LAW 125, 165 (2008);.Franck Latty, LA LEX SPORTIVA. RECHERCHE SUR LE DROIT TRANSNATIONAL (2007).

${ }^{36}$ See for this argument with reference to the Lex Mercatoria Berger, supra, note 31, 75; for a theoretical reconstruction of an autonomous law beyond the state ee Gunther Teubner, Breaking Frames: Globalisation and the Emergence of Lex Mercatoria, 5 EUROPEAN JOURNAL OF SOCIAL THEORY 199 (2002).

${ }^{37}$ See Teubner \& Korth, supra, note 14. 
argumentation which shifts the criterion for the recognition of "lawness" just to a meta-norm. ${ }^{38}$ Such an approach tends to neglect the emergent character of legal institutions which are only stabilized by secondary norms "after the fact". The following analysis tries to shed some light on the historical transformations within domestic administrative law which generate new institutions in emergent processes for a better understanding of the specificity of a global administrative law perhaps not "without the state" but with "entangled hierarchies" which do not (yet?) allow for a clear distinction of "primary" and "secondary norms".

\section{The Historical Evolution of General Administrative LaW}

\section{A. The Essence of the "Positive Law” of the Liberal Society: Its Rule-Like Character}

In a deeper sense, a law that - as one might rephrase the above-mentioned quotation from the recent book of Joyce Appleby - rests on the assumption that "nobody is in charge of the collective order", is "positive" ${ }^{39}$ As a consequence, it is "non-instrumental", in the sense that it refers to a "relationship in terms of rules". ${ }^{40}$ These rules are decoupled from substantive values, and allow for the co-ordination among agents who pursue their self-chosen goals. This assumption raises a lot of criticism about the collective and social character of the individual - a criticism which misses the point. Clearly, the individual is not - in a meaningful sense - to be presupposed as the creator of his or her own self. Individuality is - itself - a social form that underlies permanent change. ${ }^{41}$ The non-instrumentality of the "positive" law and its corresponding conception of individual freedom do not invoke the "voluntary disposition of self-interested economic actors". ${ }^{42}$ They pre-suppose an acentric society the collective order of which resides in the permanent emergence of innovations that establish a "play of ideas", ${ }^{43}$ a pool of variety that contains an excess of possibilities over reality generated from the practices of co-operation, competition, imitation, and experimentation in society. Clearly, this process generates not only spontaneously, but also in a reflexive form of second order observation of the very rules and patterns its own infrastructure, meta-rules and stabilising institutions. However, it is most important to underline that the individual as a merely "self-interested

\footnotetext{
${ }^{38} \mathrm{Cf}$. Jean d'Aspremont, Hart et le positivisme postmoderne en droit international, 113 REVUE GENERALE DE DROIT INTERNATIONAL 635 (2009); also Niklas Luhmann, LAW AS A SOCIAL SYSTEM 123, 125 et seq. (2004).

39 Joyce Appleby, THE RELENTLESS REVOLUTION: A HISTORY OF CAPITALISM 248 (2010).

${ }^{40}$ Michael Oakeshott, ON HUMAN CONDUCT 140 (1975); Terry Nardin, THE PHILOSOPHY OF MICHAEL OAKESHOTT 202 (2001); see also, Edwardf. McClennen, Rationality and Rules,13, in: Peter A. Danielson (ed), MODELING RATIONALITY, MORALITY AND EVOLUTION 13 (1998).

${ }^{41}$ See, generally, Markus Schroer, DAS INDIVIDUUM DER GESELLSCHAFT (2003); Jean-Claude Kaufmann, L'INVENTION DE SOI: UNE THÉORIE DE L'IDENTITÉ (2004); Kenneth J. Gergen, THE SATURATED SELF: DILEMMAS OF IDENTITY IN CONTEMPORARY LIFE (1992); Joanne Finkelstein, THE ART OF SELF-INVENTION (2007).

${ }^{42}$ Wolfgang Streeck, RE-FORMING CAPITALISM. INSTITUTIONAL CHANGE IN THE GERMAN POLITICAL ECONOMY 156 (2010).

${ }^{43}$ Appleby, supra, note 39, 156.
} 
economic actor" is primarily not a myth of liberal society, but one of its critics. This can be demonstrated by referring to the present discussion of the protection of the "commons" of culture against private appropriation in the digital world and its equivalent in the genetic engineering. The relationship between privately-owned knowledge and the "intellectual commons" is a permanent problem of liberal society, but one should not overlook the collective, albeit distributed, character of the core of the "common knowledge" of society, ${ }^{44}$ which was characterised by open access and restricted by patent law only to a limited extent. In the economic order of the liberal society, a "culture of improvement" ${ }^{45}$ is enshrined, which was always open to knowledge transfer which was, to a large extent, not only accepted as being unavoidable, but also as being productive for the permanent generation of technological innovation and competition. This process does not exclude "public intervention" - on the contrary, apparently, the public knowledge infrastructure in countries such as Germany in the 19th century had a positive impact on the culture of innovation. ${ }^{46}$

\section{B. The Generation of the "Acte administratif" as the Main form of Administrative ACTION IN THE "SOCIETY OF THE INDIVIDUALS"}

The focus on legitimation and the derivative logic of the "application" of norms to cases misses the internal dynamics of the legal system, which is due to the subjective right as an institution which not only opens the potential for societal self-organisation of the economy, politics, the arts, etc., but also opens society towards a distributed rationality of continuous transformation because it changes the temporal orientation from the past (the "given" and its reproduction as the aim of society) to the future and the uncertainty that it generates. The legal norms basically do not "steer" society in modernity, but protect the self-organisational potential inherent in the unrest which it introduces in the "society of the individuals". ${ }^{47}$ This self-organisational potential comes to the fore when the legal system is challenged by the dynamic knowledge base which generates "experience" as a distributed type of knowledge which no longer accepts a central privileged point of observation of society which is either "given" by tradition or claimed to be possessed by the political sovereign power in the European absolutist states. ${ }^{48}$ In Germany, this "sovereign" knowledge, which combines normative and empirical aspects in as much as it

\footnotetext{
${ }^{44}$ See for this concept Herbert Gintis, Rationality and Common Knowledge, 22 RATIONALITY AND SOCIETY 259 (2010).

${ }^{45}$ Robert Friedel, A CULTURE OF IMPROVEMENT: TECHNOLOGY AND THE WESTERN MILLENNIUM (2007).

${ }^{46}$ See generally Rainer Wolf, DER STAND DER TECHNIK (1986); Milos Več, RECHT UND NORMIERUNG IN DER INDUSTRIELLEN REVOLUTION 272, 367 (2006).

${ }^{47}$ See only Appleby, supra, note 39, 248.

${ }^{48}$ See on the emergence of the public knowledge that is needed for the government of the absolutist state Michel Senellart, LES ARTS DE GOUVERNER. DU REGIMEN MEDIEVAL AU CONCEPT DE GOUVERNEMENT, 236 et seq. (1995).
} 
claims that the administrative state holds this privileged position which allows us to know what the requirements of the public order are, is termed "Polizeywissenschaft" ("police science"). ${ }^{49}$

The new administrative law of the second half of the 19th century ${ }^{50}$ undergoes a fundamental change when it accepts that the concept of order mainly refers to a factual normality and its description by societal experience, and is no longer based upon the traditional knowledge of the sovereign state. ${ }^{51}$ This is why it would be superficial to take the "acte administratif" ("Verwaltungsakt"), the sovereign unilateral administrative decision that has binding force even if it is not in conformity with the law, at face value. ${ }^{52}$ It is meant to to deliver "fixed points" in the "floating mass of administrative activities". ${ }^{53}$ Both legislation and legal doctrine were more interested in very broad issues of the general legal order, whereas the operation with the increasing complexity of technical knowledge and industrial innovation were left to the discretion of administrators. ${ }^{54}$ The "acte administratif" corresponds to the distributed logic of the "private law society" (Privatrechtsgesellschaft) ${ }^{55}$ which processes innovation, experiment and social experience. ${ }^{56}$ The authoritarian character ${ }^{57}$ of the "acte administratif"

${ }^{49}$ Matthias Bohlender, Metamorphosen des Gemeinwohls - von der Herrschaft guter polizey zur Regierung durch Freiheit und Eigentum, 247, in: GEMEINWOHL UND GEMEINSINN -HISTORISCHE SEMANTIKEN POLITISCHER LEITBEGRIFFE (Herfried Münkler \& Harald Bluhm, eds,. 2001).

50 See for the development in Germany Michael Stolleis, GESCHICHTE DES ÖFFENTLICHEN RECHTS IN DEUTSCHLAND, VOL 2: 1800 - 1914, 410 et seq. (1992): the concept had found its contours only at the end of the $19^{\text {th }}$ century; the same goes for France, cf. Philippe Belaval, Foreword, in: Cédric Milhat, L'ACTE ADMINISTRATIF: ENTRE PROCESSUS ET PROCEDURES 7 (2007).

${ }^{51}$ In a theoretical perspective see Pierre Macherey, PETITS RIENS. ORNIÈRES ET DERIVES DU QUOTIDIEN 21 (2009); id., DE CANGUILHEM À FOUCAULT. LA FORCE DES NORMES 77 (2009).

52 The focus of German (and French) administrative law on the Verwaltungsakt ("acte administratif") is said to have focused on state intervention and to have neglected the role of the administration in the development of benefits administration and infrastructure in particular, Kersten \& Lenski, supra, note 9, at 504; but this is far from convincing because the American evolution follows the same track without being focused on the "administrative act", Mashaw, supra, note 7.

${ }^{53}$ Otto Mayer, DEUTSCHES VERWALTUNGSRECHT, Vol. I, 95 (1914).

54 Več, supra, note 46, 281; Erk-Volkmar Heyen, Deutschland, in: GESCHICHTE DER VERWALTUNGSRECHTSWISSENSCHAFT IN EUROPA 29, 32 (id., ed., 1982); H. Berthélémy, TRAITÉ DE DROIT ADMINISTRATIF ÉLÉMENTAIRE, 8th ed., 354 et seq. (1916) for the regulation of „installations classées”.

${ }^{55}$ It is not a coincidence that one of the founders of modern public law in Germany, Carl Friedrich von Gerber (GRUNDZÜGE EINES SYSTEMS DES DEUTSCHEN STAATSRECHTS, $2^{\text {nd }}$ ed., 1869) was first a private lawyer; his focus on the "will power" ("Willensmacht") of the state and its putative "blindness" to political goal finds its reverse side in the openness toward the observation of the social dynamic of a liberal society; see also Carsten Kremer, DIE WILLENSMACHT DES STAATES. DIE GEMEINDEUTSCHE STAATSRECHTSLEHRE DES CARL FRIEDRICH VON GERBER, 296 (2008) (for the relationship between goals and "willpower").

${ }^{56}$ The work by Reimund Schmidt-De Caluwe, DER VERWALTUNGSAKT IN DER LEHRE OTTO MAYERS 63 et seq. (1999) and Michael Stolleis, GESCHICHTE DES ÖFFENTLICHEN RECHTS IN DEUTSCHLAND, Vol. II, 332 et seq. (1992) overstate the political connotation of the emerging German administrative law in the $19^{\text {th }}$ century and neglect its internal rationality; more differentiated Thomas von Danwitz, VERWALTUNGSRECHTLICHES SYSTEM UND EUROPÄISCHE INTEGRATION 31 et seq. (1996); Roger Müller, VERWALTUNGSRECHT ALS WISSENSCHAFT,FRITZ FLEINER 1867 - 1937, 100 (2006). 
(Verwaltungsakt) should not be taken at face value; it is an extremely modern instrument that that has demonstrated its flexibility even under postmodern conditions of complexity. ${ }^{58}$ It is a form of a flexible public intervention that corresponds to the character of the positivist law "without a goal" of its own.

The "acte administratif" has both an external function (in the limitation of subjective rights) and an internal function which allows administration to process rational decision-making on a caseby-case mode ${ }^{59}$ from which a structure emerges which can be deciphered both by the administrative practitioners themselves and by private actors. If this process is not in line with the experience diffused and reproduced by society, and if it comes into conflict with the rights of the private actors, it can be controlled by courts with reference to the rationality of the decision-making process itself. This conflict gives courts the opportunity to re-process the "actes administratifs" in a network of judicial decisions with a view to the legitimate expectations which can be formulated and further processed upon the basis of the "rights" of private actors. In this way, the "acte administratif" is "re-coded" as an infringement in personal rights while, at the same time, it is processed in the administrative decision-making procedures which contribute to the stabilisation of the impersonal inter-relationships ${ }^{60}$ which allow for the self-organisation of society. This evolution corresponds to the rise of "realism", a social ideology that challenges the holistic conceptions of German idealism and opens a perspective on the dynamic of "will power as the point of departure for a new construction of society - as distinct from tradition. ${ }^{61}$

Here, we are confronted with the blind spot of the legal system, which demonstrates difficulties in acknowledging the process-like acentric character of the evolution of its own frames of reference. It is not by coincidence that Philippe Belaval, a member of the French Conseil d'Etat, in his preface to a book on the modern use of the "acte administratif" refers to the "plurality of the architects" of the concept ${ }^{62}$ - a view that pre-supposes that the elements of architectural

\footnotetext{
${ }^{57}$ The focus on willpower fits in the general trend towards a social-darwinian "vitalism" as a far spread everyday philosophy in Germany that is neither liberal in a political sense nor democratic but not antimodern; see Jürgen Große, LEBENSPHILOSOPHIE 89, 101 (2010), where the momentary expression of willpower in response to a situation is highlighted.

${ }^{58}$ Karl-Heinz Ladeur, Die Zukunft des Verwaltungsakts, 86 VERWALTUNGSARCHIV 511 (1995)..

${ }^{59}$ Marcel Gauchet, L'Etat au miroir de la raison d'Etat: La France et la chrétienté, in: RAISON ET DERAISON D'ETAT 193, 237 (Yves-Charles Zarka, ed.,1 994).

${ }^{60}$ Douglass C. North, John J. Wallis \& Barry R. Weingast, VIOLENCE AND SOCIAL ORDERS: A CONCEPTUAL FRAMEWORK FOR INTERPRETING RECORDED SOCIAL HISTORY 261 (2009).

${ }^{61}$ See the wonderful book by Jacques Le Rider, L'ALLEMAGNE AU TEMPS DU RÉALISME. DE L'ESPOIR AU DÉSENCHANTEMENT 1848 - 1890, 33, 46, 52 (2008).

${ }^{62}$ Belaval, supra, note $50,7$.
} 
design are pre-determined and given. ${ }^{63}$ From a postmodern perspective that takes into consideration the approaches of comparative research in literature which try to describe the text as a paradoxical effect of an anonymous intertextuality, the co-presence of other texts which interfere with the production of meaning beyond the will of the author, ${ }^{64}$ one might get an idea of how basic concepts of public law such as the "acte administratif" (Verwaltungsakt) in continental European law can only be regarded as the result of a process that writes itself within an "environment of possibilities" ("environnement des possibles"). ${ }^{65}$ It is the emergent product of a discontinuous process of variation of cases, the stabilisation of "local equilibria", and of transcending them in crises and of the search for new "local equilibria". ${ }^{66}$ Certain possibilities are given up, others are retained and interwoven in a multitude of inclusive options and exclusive constraints. ${ }^{67}$ This inter-disciplinary approach sheds some light on the distribution of competencies between administration, administrative courts and the legislator. The focus on legitimation is misleading, because it tends to reduce the processing of the administrative act to its "would-be" origin in the Ancien Régime and to oppose it to the democratic will as the only acceptable source of legitimation. Without a "discursive memory" that links - in retrospect - the distributed intertextuality of the implicit ${ }^{68}$ construction of a basic legal institution to a prospective generative dimension within a domain of options that is only - to a limited extent the object of explicit design, a productive role of the legislation is inconceivable. ${ }^{69}$

\footnotetext{
${ }^{63}$ See from a perspective of the humanities Michel Charles, INTRODUCTION À L'ÉTUDE DES TEXTES 221 (1995).

${ }^{64}$ Gérard Genette, PALIMPSESTES. LA LITERATURE AU SECOND DEGRÉ 8 (1982).

${ }^{65}$ Charles, supra, note 63, 102.

${ }^{66}$ Charles, supra, note 63, 102.

${ }^{67}$ This reference to the acentric intertextuality of the selftransformation of law may in fact be more adequate to legal theory than the focus on "evolution" which can only be used in a more or less metaphorical way because there is no functional equivalent to genes in the legal system; see for the observation of oscillatory processes at the "borders" of the legal system Fabian Steinhauer, GERECHTIGKEIT ALS ZUFALL. ZUR RHETORISCHEN EVOLUTION DES RECHTS 94 (2007); Marc Amstutz, EVOLUTORISCHES WIRTSCHAFTSRECHT 271 et seq. (2001); Gunther Teubner, AUTOPOIETIC LAW: A NEW APPROACH TO LAW AND SOCIETY 221et seq., 226 (1988) (the focus on "pattern prediction" still remains vague and is ignorant of selftransformation processes that the system cannot control), Niklas Luhmannn, DIE GESELLSCHAFT DER GESELLSCHAFT, Vol. 1, 549 (1997) takes the view that the "evolution of ideas" is context dependent and does not underlie the control by argumentation - what this means for the evolution of system remains unclear; critically Robert W. Gordon, Critical Legal Histories, 36 STANFORD LAW REVIEW 57, 81 (1984); also Lawrence Rosen, LAW AS CULTURE 56 et seq. (2006).

${ }^{68}$ Michael Polanyi, PERSONAL KNOWLEDGE. TOWARDS A POST-CRITICAL PHILOSOPHY (1998).

${ }^{69}$ This does not mean that no radical reform is possible because the model that could only be briefly sketched cannot exclude that search processes end in a lock-in that blocks any productive experimentation; see the paper by Daron Acemoglu, Davide Cantoni, Simon Johnson \& James A. Robinson, The Consequences of Radical Reform: The French Revolution, Discussion Paper 2010, http://econ-www.mit.edu/files/5644 (arguing plausibly that the Napoleonic reforms introduced in several German territories at the beginning of the $19^{\text {th }}$ century had lasting positive effects on the economic development.
} 
This is why the requirement of a democratic legitimation for both private and public law can only be acknowledged to a very limited extent. ${ }^{70}$ The administrative law of the "society of individuals" is closely linked to the logic of private law and its reference to the self-organisation of differentiated societal systems (the economy in particular). It introduces a similar logic into public law because its cognitive frame of reference is now the society and its practical knowledge basis and not "police science" as in the past. ${ }^{71}$ Police power, which is the core of administrative decision-making, refers to a societal dynamic conception of the "normality" 72 not to factual tradition and not to a privileged knowledge possessed by the state. ${ }^{73}$ However, the close link between the normative and cognitive elements of the definition and the protection of "public order" is preserved, ${ }^{74}$ even though it has to be observed and reflected in a much more sophisticated mode than in the past. ${ }^{75}$ This is all the more the case because knowledge takes on a dynamic character itself ${ }^{76}$ - in the same vein as the law. The state makes itself "understandable" by laying open the knowledge base which it wants to establish for

\footnotetext{
${ }^{70}$ See Ralph Michaels, Umdenken für die UNIDROIT Prinzipien: Vom Rechtswahlstatut zum Allgemeinen Teil des transnationalen Vertragsrechts, 73 RABELS ZEITSCHRIFT FÜR AUSLÄNDISCHES UND INTERNATIONALES PRIVATRECHT 866 (2009).

${ }^{71}$ Bohlender, supra, note 49; the mostly smaller German states in the late $17^{\text {th }}$ and early $18^{\text {th }}$ century had tried to epitomise an administrative rationality as the legitimation basis of public power, Yves-Charles Zarka, PHILOSOPHIE ET POLITIQUE À L'ÂGE CLASSIQUE 158 (1998); Michel Senellart, LES ARTS DE GOUVERNER. DU REGIME MEDIEVAL AU CONCEPT DE GOUVERNEMENT 282 (1995); id., "Juris peritus, id est politicus"? Bodin et les théoritiens allemands de la prudence civile politique au XVIle siècle, 201, 216 et seq., in: JEAN BODIN. NATURE, HISTOIRE, DROIT ET POLITIQUE (Yves-Charles Zarka, ed.,1996) this allowed for the development of a compromise between an approached which remained focused on the state and an approach which described the state as a function of society. Because of the rise of a fragmented "special knowledge" as a basis for public decision making it seems doubtful that the concept of "police science" can be revitalized under conditions of postmodernity, See however the contributions in: THE NEW POLICE SCIENCE. THE POLICE POWER IN DOMESTIC AND INTERNATIONAL GOVERNANCE (Markus D. Dubber \& Mariana Valverde, eds., 2006).

72 See the famous "Kreuzberg"-judgment of the Prussian Higher Administrative Court (Oberverwaltungsgericht) of June $14^{\text {th }}, 1882$, Reports (OVGE)) Vol. 9, 353; See Volkmar Götz, ALLGEMEINES POLIZEI- UND ORDNUNGSRECHT, $13^{\text {th }}$ ed., 18 (2001); for the historical development in France, in particular the flexibility of the emerging police law see Paolo Napoli, NAISSANCE DE LA POLICE MODERNE: POUVOIRS, NORMES, SOCIÉTÉ 15 (2003).

${ }^{73}$ Bohlender, supra, note 49; for the US see T. R. Powell, Administrative Exercise of the Police Power, 24 HARVARD LAW REVIEW 268 (1911); for France Senellart, supra, note 48.

${ }^{74}$ Paolo Napoli, Misura di polizia. Un approccio storicoconcettuale in età moderna, 44 QUADERNI STORIC I 523 (2009).

${ }^{75}$ For the broad conception of "police" in the ancien regime See Pasquale Pasquino, THEORIES OF THE STATE IN EARLY-MODERN EUROPE 42, 61, in: Dubber \& Valverde (eds.), supra, note 71.

${ }^{76}$ One element of the new coordination between state and society in the $19^{\text {th }}$ century is the rise of statistics and its use by both public and private actors: Theodore M. Porter, Lawless Society: Social Science and the Reinterpretation of Statistics in Germany, 1850-1880, 351, in: THE PROBABILISTIC REVOLUTION , VOL. 1 (Lorenz Krüger, Lorraine J. Daston \& Michael Heidelberger, eds.,1987).
} 
administration ${ }^{77}$ and the world has to be made calculable. ${ }^{78}$ "Experience" is based upon selftransformation of society as is the legal system. ${ }^{79}$ This new perspective changes the status or the rule in general: it is generated "bottom up" from individual behaviour, and not from a totalising point of view, ${ }^{80}$ which would be incompatible with the experimental order established by private law. This new dynamism comes to the fore both in police law, which observes the new economic and technical dynamism referring to the distinction of "danger"/normality (in conformity with experience), and models its "control project" on the patterns of the societal self-understanding of technology (control of steam engines, gas containers, safety of buildings, etc.). ${ }^{81}$ The "normal" is not dangerous. ${ }^{82}$ The same is true for private law where, for example, the requirements of the conclusion of a contract or the definition of "negligent" (unlawful) behaviour refer to experience emerging in society.

The state even intervenes in the activities to distribute experience in society when its knowledge remains restricted to local or regional communities. It presses for the establishment of private self-organised organisations which are meant to evaluate and promote experience which can be regarded as reliable (Technischer Überwachungsverein, TÜV, Verein Deutscher Ingenieure, VDI, etc.). ${ }^{83}$ This shows that the legal system cannot be onlycognitively open on a case-to-case basis and adhere to stable legal rules at the general level: there is a continuous exchange between a normalised societal experience which is increasingly formulated in technical rules for the construction of machinery, or the construction of buildings. And both private law and public law have to refer to this "normal" knowledge" when it comes to the question of whether damage (caused by the explosion of a gas container, for example) was to be attributed to "negligence" (ex post) or whether it had to be regarded as "dangerous" by police (ex ante). This does not mean that the economic system or technology impose certain rules on the legal system and call its self-construction into question - not at all. Legal rules cannot be processed without a reference to societal rules and the self-generated "internal law" of administration ${ }^{84}$ - this constitutive link between recurring patterns of behaviour in society

\footnotetext{
${ }^{77}$ Marcel Gauchet, L'Etat au miroir de la raison d'Etat: La France et la chrétienté,193, 237 in: RAISON ET DERAISON D’ETAT (Yves-Charles Zarka, ed.,1994).

${ }^{78}$ Alain Desrosières, THE POLITICS OF LARGE NUMBERS. A HISTORY OF STATISTICAL REASONING (1998); François Ewald, L'ETAT PROVIDENCE (1986); Theodore J. Porter, THE RISE OF STATISTICAL THINKING (1986).

${ }^{79}$ Alexandre Lefebvre, THE IMAGE OF LAW. DELEUZE, BERGSON, SPINOZA 15 (2008).

${ }^{80}$ Claude Gauthier, L'INVENTION DE LA SOCIÉTÉ CIVILE 233 (1993).

${ }^{81}$ The police power as a "governmental practice" of the state preserves its forms but it exchanges the cognitive schemes it draws on; see Paolo Napoli, "Police". La conceptualisation d'un modele juridico-politique sous I'Ancien Régime, 20 DROITS 183 (1994) and 21 DROITS 151 (1995).

82 Karl-Heinz Ladeur, Coping With Uncertainty: Ecological Risks and the Proceduralisation of Environmental Law, 299, in: ENVIRONMENTAL LAW AND ECOLOGICAL RESPONSIBILITY: THE CONCEPT AND PRACTICE OF ECOLOGICAL SELF-ORGANIZATION (Gunther Teubner, Lindsay Farmer \& Declan Murphy, eds., 1994).

${ }^{83}$ Wolf, supra, note 46.

${ }^{84}$ Mashaw, supra, note 7, 1413, 1461; the concept goes back to Bruce Wyman, THE PRINCIPLES OF ADMINISTRATIVE LAW GOVERNING THE RELATIONS OF PUBLIC OFFICERS (1903).
} 
and the normative patterns which have to be constructed, observed and tested in the legal system is essential to the legal rationality. ${ }^{85}$ This does not mean that normal knowledge is just blindly introduced into the legal system. On the contrary, the legal system can, and has to, observe whether these practical rules are sufficient, reliable, have to be modified upon the basis of new experience, etc. Normality and normativity are closely linked, and this link is continuously observed, revised and re-modelled.

Administrative law is driven by two contradictory forces: on the one hand, the administrative agents behave as a "community of experimentalists", ${ }^{86}$ which operates with a kind of implicit horizontal linking from case-to-case, whereas courts, on the other hand, have a tendency towards a type of explicit conceptual re-coding, which tries to limit the processes of selforganisation that are necessarily inherent in the administrative practice. There is a permanent interplay between these two types of internal and external stabilisation of the administrative legal process. However, it would be superficial to regard the judicial practice as the creator of the institutions of administrative law. ${ }^{87}$ Its stabilisation is the outcome of a co-operative process which is only moulded in statute law much later. This process can be regarded as a distributed evolutionary process ${ }^{88}$ which draws upon the different functions of administration and judiciary. ${ }^{89}$ The autonomy of the "relational rationality" of administrative decision-making should not be derived from "expertise" ${ }^{90}$ in a stricter analytical sense, but is due to the evolutionary character of the dynamic self-transformation of society: this evolutionary process which subsumes administrative law to a permanent unrest from which new patterns and instruments of decision-making are generated can be described as drawing on an "abductive" approach (following the terminology of Charles S. Peirce) ${ }^{91}$ which is a reasoning that creates a new meaning from the observation of "cases" and conflicting rationales, and leads to a broadening perspective on the societal pool of variety beyond the possibility of inferring a new stable rule that can be "applied". ${ }^{92}$ It is more a kind of a "move" within a game with incomplete

\footnotetext{
${ }^{85}$ Lefebvre, supra, note 79, 59.

${ }^{86}$ See generally Peter Ochs, Peirce, PRAGMATISM AND THE LOGIC OF SCRIPTURE 107 (1998).

${ }^{87}$ Mashaw, supra note 7, 1378.

${ }^{88}$ See Müller, supra, note 56, 86 in particular; generally Wolfgang Meyer-Hesemann, METHODENWANDEL IM VERWALTUNGSRECHT (1981).

${ }^{89}$ See for a critique of the Chevron-approach Elizabeth V. Foote, Statutory Interpretation or Public Administration: How Chevron Misconceives the the Function of Agencies and Why it Matters, 59 ADMINISTRATIVE LAW REVIEW 673, 677 (2007).

${ }^{90}$ See for this argument Long Island Care at Home Ltd. v. Coke, S. Ct. 127 2339, 2346-47 (2007).

${ }^{91}$ Christiane Chauviré, Peirce et la signification. Introduction à la logique du vague 201 (1995).

92 See in defense of the rationality of administrative decision making Jerry L. Mashaw, Norms, Practices, and the Paradox of Deference: A Preliminary Inquiry into Statutory Interpretation, 57 ADMINISTRATIVE LAW REVIEW 501 (2005).
} 
rules which emerge from the game itself. This is a logic of incompleteness that is not accessible from a control-project which epitomises conformity to rules.

But to describe administrative law and its institutions in the 19th century as judge-made law misses the point: it is mainly an autonomous product of administration itself both in Europe and the US:

"The structures and processes of administrative adjudication were designed and built almost entirely by the administrative agencies themselves." ${ }^{93}$

This is true also for the US: Jerry L. Mashaw has epitomised the generation of "transsubstantive" internal rules of decision-making by administrative decision-makers in the 19th century. ${ }^{94}$ For the US, it is quite characteristic that the existence of much of this earlier administrative law was even denied at all, ${ }^{95}$ mainly because it did not fit in the model of accountability and legitimacy of law. The US administrative law is not based upon a focal construction like the French and German "acte administratif" ("Verwaltungsakt"); however, it is also centred on the search for the adequate forms of intervention into individual rights and the processes of self-organisation that their use unleashes. ${ }^{96}$

C. INTERMediary Remarks on the EMBeddedness of the Legal System in the "Epistemic KNOWLEDGE BASE" OF SOCIETY

Historians of social and economic institutions, such as Joel Mokyr, have underlined - with good reasons - the hypothesis that one should not over-estimate the role of formal institutions in the evolution of modern western societies. ${ }^{97}$ Cultural beliefs and self-enforcing practices of trustbuilding and reputation were at least as important as formal institutions. ${ }^{98}$ The complex legal system is rooted in a broader "epistemic knowledge base". We will see later that the one-sided perspective on the legal system in the stricter sense leads to futile questions on what the legal nature of "global administrative law" really is. ${ }^{99}$ This approach either leads to the fixation of a traditional static concept of law or the problematical assumption that a global civil society can

\footnotetext{
${ }^{93}$ Mashaw, supra, note 7.

${ }^{94}$ Mashaw, supra, note 7, 1377, 1466.

${ }^{95}$ Mashaw, supra, note 7, 1378.

${ }^{96}$ Frank J. Goodnow, COMPARATIVE ADMINISTRATIVE LAW 6 et seq., 371 et seq. (1905).

97 Joel Mokyr, INSTITUTIONAL ORIGINS OF THE INDUSTRIAL REVOLUTION, 4, 22 (2008).

${ }^{98}$ Avner Greif, INSTITUTIONS AND THE PATH TO MODERNITY: LESSONS FROM MEDIEVAL TRADE (2006); Douglass C. North, UNDERSTANDING THE PROCESS OF ECONOMIC CHANGE (2010).

${ }^{99}$ See only Kingsbury, supra, note 9; for the relationships between global administrative law and traditional international law Sabino Cassese, B. Carotti, L. Casini, M. Macchia, E. Macdonald \& M. Savino, GLOBAL ADMINISTRATIVE LAW. CASES, MATERIALS, ISSUES, $2^{\text {nd }}$ ed., p. XXV www.iilj.org,
} 
be regarded as generating and "constitutionalising" its own legal system beyond the state. ${ }^{100}$ The focus should, instead, be on the permanent unrest inherent in the experimental acentric order of (post-) modern society which introduces an evolutionary "drift" ${ }^{101}$ into the cultural memory of society, which is also a challenge for the legal system, because there is a close interrelationship between the cognitive and the normative rationality of society.

The knowledge order of society was (and is) constituted in a way which not only differentiates between general knowledge ("in the books" and in practical experience) and privately appropriated information (legally-protected by patents or practical processes of keeping knowhow secret in firms) but also left open a broad range of operations of freely-sharing information (which seems to be regarded by many protagonists of the internet world as something completely new - which is definitely not the case). Robert C. Allen calls this phenomenon "collective invention" ${ }^{102}$ which includes, for example, the spread of the steam engine as a basic innovation of the 19th century. Especially in the UK and later also in Germany and other countries, social conventions and "self-enforcing modes of behaviour"103 were much more important for the stabilisation of the legal system than the formal adjudication by independent judges in ividual cases of conflict. It is quite characteristic that the goals of policing in Germany included the preservation of "public order" (as opposed to "public security" 104 in the narrower sense) i.e., the observation of the "appropriate" behaviour in public and the respect for social conventions (below the level of formal law) such as disciplined and controlled self-presentation in public including basic norms of politeness, clothing, cleaning, sexuality, ${ }^{105}$ etc.

These remarks should have made it clear that, in the "society of individuals"106 of the 19th century, both public and private law were based upon complex layers of social knowledge, conventions and professional practices, all of which were enshrined in the public order at large or in social and technical experience. Without reference to this cognitive infrastructure, neither private nor administrative decision-making can be understood.

\footnotetext{
${ }^{100}$ for a critique see also Möllers, supra, note 25, 329; Christian Tietje, Transnationales Wirtschaftsrecht aus öffentlich-rechtlicher Perspektive, 101 ZEITSCHRIFT FÜR VERGLEICHENDE RECHTSWISSENSCHAFT 404, 418 (2002); Rost, supra, note 35, 87.

${ }^{101}$ Francisco J. Varela, Evan Thompson \& Eleanor Rosch, THE EMBODIED MIND: SCIENCE AND HUMAN EXPERIENCE 200 (1993)

102 Robert C. Allen, Collective Invention, 4 JOURNAL OF ECONOMIC BEHAVIOR 1 (1983); Mokyr, supra, note 97, at 22.

${ }^{103}$ Mokyr, ibid., 12.

${ }^{104}$ For Germany see Volkmar Götz, ALLGEMEINES POLIZEI- UND ORDNUNGSRECHT, $13^{\text {th }}$ ed., 43 (2001).

${ }^{105}$ See for the policing of prostitution Jacques Berlière, LA POLICE DES MOEURS SOUS LA IIIE RÉPUBLIQUE (1992).

${ }^{106}$ Nobert Elias, supra, note 11.
} 
The "administrative act" was, as seen in the perspective opened here, not a relict of the absolutist state, but a modern instrument of rationalising administrative practices and of coordination between the society of the individuals and the preservation of "public order" ${ }^{107}$ It turns it into the new experimental order that can no longer draw on a fixed set of rules and traditions. Its new form is a product of the evolutionary "drift" of the development of administrative law, which can only ex post be stabilised by "judge made law" or later by the legislator.

\section{The Secondary Re-Modelling of the Traditional Administrative LaW of the Society of THE INDIVIDUALS}

The exchange process between the law and the structured practical networks which generate and distribute societal experience is in constant flux. ${ }^{108} \mathrm{~A}$ distinction has to be made between the continuous flow of information which emerges from the permanent variation within societal knowledge basis, and the momentary suspension of normality by the rise of new factual paradigms which induce a kind of "break of symmetry" in the inter-relationship between technical normal knowledge and the feedback loops which have to be designed within the legal network of networks. This was, for example, the case when the knowledge process became more dynamic and, as a consequence, the concept of normality had to be re-framed: increasingly, this dynamic is reflected in the legal system when the question is raised as to whether bigger firms have a duty to take an active part in the creation of knowledge and are no longer allowed just to adapt to the current "state of the art" 109 or when (in administrative law) the orientation on experience and "danger" (in the end: damage) is at stake.

The hitherto central unilateral administrative decision is in decline - not only in global administrative law. Things get more complicated to judge if one bears in mind that this is also true for domestic law. At the global level in particular, not only informal measures and procedures take the lead over the "acte administratif" as expression of the internal sovereignty of the state, but also the norms which are referred to in global law are mainly not legal norms which are part of international public law, but factual standards or, if one may put it this way, self-organised "norms in being", procedural rules in particular.

The same goes for the concept of "person" as a cornerstone of the liberal positive legal order: this concept draws on the stability of roles and the attribution of future-oriented expectations to legal actors abstracted from the stability of tradition. ${ }^{110}$ Once the person is supplemented by

\footnotetext{
${ }^{107}$ Gauchet, supra, note 77.

${ }^{108}$ For an overview of the function of the "Verwaltungsakt" in present day German administrative law see Christian Bumke, Verwaltungsakte, 1031, in: GRUNDLAGEN DES VERWALTUNGSRECHTS, VOL. 2 (Wolfgang Hoffmann-Riem, Eberhard Schmidt-Aßmann \& Andreas Voßkuhle, eds., 2008).

${ }^{109}$ For the different bridging concepts that are used for the transfer of knowledge into the legal system see Ladeur, supra, note 83.

${ }^{110}$ Irène Théry, LA DISTINCTION DE SEXE: UNE NOUVELLE APPROCHE DE L’EGALITE 384 et seq. (2010).
} 
the organisation and - recently - by networks of relationship, one may assume that the fundamental relevance of the person has changed, as well. The role of the person is mediated by its position in organisations and networks. ${ }^{111}$ Expectations can be multi-faceted under both conditions of complexity ${ }^{112}$ and the dynamic of self-transcendence of liberal society. This dynamic allows for a new type of reflexivity of the legal order, which can operate with an open linkage between norms in the stricter sense and a whole range of different types of "social norms" ${ }^{113}$ which, in the past, remained more or less hidden in the administrative practices. ${ }^{114}$ Both components of the normative order are permeable for a reflexive acentric modelling of "expectations of expectations" both by and between organisations that have more strategic potential, in as much as they can construct longer chains of actions.

The new reflexivity gives sufficient space for a "management of rules" which re-models the distinction between legal and factual norms: the spontaneous character is replaced more and more by explicit "standards" that demonstrate a new fragmentation and heterogeneity within the social knowledge base: experience based knowledge has to distinguished from the "best available knowledge", ${ }^{115}$ in particular. Knowledge is further dynamised. This development includes the necessity to find procedural meta-norms for the observation of the new versions of the "loops" between both types of rules because there are, of course, problems which raise the question of how a norm has to be characterised: this is the case when the rights of persons who did not participate in the creation of the norm are infringed. However, this is not often to be assumed, because, in the society of organisations, ${ }^{116}$ persons are, in many constellations, legally represented by organisations or are subsumed under new general patterns of expectations beyond the classical "no harm" principle (for example, protection by public insurance, transformation of liability, including strict liability, the creation of group rights, such as the rights of workers and consumers). Often, no external effect of norms can be observed because it is only the general framework of decision-making that is touched by an organisational process. Many social norms are more a kind of functional equivalent to the process of self-construction of experience as a collective, distributed knowledge base.

\footnotetext{
${ }^{111}$ The reverse side is to be seen in the fact that the natural person as opposed to the "legal person" in the stricter sense has also been transformed: Increasingly norms are integrated into the legal system that refer to the individual "personality" as the object of care and assistance.

${ }^{112}$ Théry, ibid., 140.

${ }^{113}$ It is not a coincidence that at the beginning of the $20^{\text {th }}$ century neither doctrine nor legislation had taken much account of the relationship between legal and social norms, Več, supra, note 46, 281.

${ }^{114}$ Calliess \& Zumbansen, supra, note 24, 250 et seq.

${ }^{115}$ For the meaning of this and other bridging concepts in environmental law see Ladeur, supra, note 83..

${ }^{116}$ For the concept see James S. Coleman, Social Structure and a Theory of Action, in: Peter M. Blau (ed.), APPROACHES TO THE STUDY OF SOCIAL STRUCTURES (Peter M. Blau, ed., 1975) 76; Charles S. Perrow, COMPLEX ORGANIZATIONS. A CRITICAL ESSAY, $3^{\text {rd }}$ ed. (1986).
} 
The more complex type of administrative decision-making that comes to the fore in the domains of planning, high technology (nuclear power, genetic engineering) and risk, in particular, demonstrate that the construction of a balancing decision in these fields is not equivalent to the classical type of a judgment based upon a "statutory interpretation" ${ }^{117}$ This was the basis for the German legal conception of a structured process of planning that distinguishes the stable and the creative elements of decision-making. More often than not, the difference between public and private decision-making is not so fundamental: in both cases, the underlying legal norms are (mainly) not applied (when one can speak about a realm of discretion) but are referred to as limits to a self-organised practice of administration or a publicprivate "joint venture".

The interplay between administrative decision-making and the law is historically changing: the external legislative norm or the judicial decision-making processes can exercise their stabilising role once a certain "internal" administrative practice has settled in a rule-like manner, while, in times of transformation, administrative horizontal-heterarchical approaches of processing from case-to-case in a creative way tend to experiment with new forms of administrative operation that do not follow rule-like patterns. This is creative function which one may call the "modernising mission", which David A. Strauss ${ }^{118}$ attributes - with good reason - to the judiciary, but which includes - in a differentiated way - the administration, as well.

One has to accept that, from the outset, the public dimension of technical (and, later on, the more complex technological) risks and the private process of production are entangled. Technologies in postmodern society are more dependent on complex design and are "hybrid", in as much as they often pre-suppose the development of a whole domain of options including far reaching potential side-effects on third parties or on human values (nuclear power, genetically modified organisms, nano-technology, etc.). However, technological questions have always had a societal dimension. ${ }^{119}$

In environmental law, ${ }^{120}$ the pivotal role of the practical experience based upon the observation of damage is called into question, ${ }^{121}$ and the control project for high technology trajectories has to be adapted to risk management and the precautionary principle, upon which

\footnotetext{
117 See for Germany Rainer Wahl, Herausforderungen und Antworten: Das Öffentliche Recht der letzten fünf Jahrzehnte 43, 51 (2006).

${ }^{118}$ The Modernizing Mission of Judiciary Review, 76 CHICAGO LAW REVIEW 859, 894 (2009).

${ }^{119}$ Frank Fischer, DEMOCRACY AND EXPERTISE. REORIENTING POLICY INQUIRY 143 et seq. (2009)

${ }^{120}$ Daniel C. Esty, Toward Optimal Environmental Governance, 74 NEW YORK UNIVERSITY LAW REVIEW 1495 (1999); id \& Maria H. Ivanova, Revitalizing Global Environmental Governance: A Function-Driven Approach, 181, in: GLOBAL ENVIRONMENTAL GOVERNANCE: OPTIONS AND OPPORTUNITIES (id., eds., 2002); Oran R. Young, INTERNATIONAL GOVERNANCE: PROTECTING THE ENVIRONMENT IN A STATELESS SOCIETY (1994); Daniel Bodansky, The Legitimacy of International Governance: A Coming Challenge for International Environmental law?, 93 AMERICAN JOURNAL OF INTERNATIONAL LAW 596 (1999).

${ }^{121}$ Karl-Heinz Ladeur, The Introduction of the Precautionary Principe into Ec Law - A Pyrrhic Victory for Environmental and Public Health law?, 40 COMMON MARKET LAW REVIEW 1455 (2003).
} 
it is based. For our perspective, it is important to bear in mind that these deep transformations within the technological networks and the legal network of practices which try to learn from them find their repercussion in the legal system, albeit only partially.

One of its major transformations is to be seen - from the "cognitivist" point of view taken here, i.e., the observation of the emergence and transformation of rules and institutions as elements of a societal memory - in the rise of the groups and organisations as the actors and as the generators of new types of knowledge in particular: the increasing importance of probabilities, groups with statistical regularities, the evolution of technologies of production and management ("expert knowledge" 122 as opposed to distributed "experience" based upon action and upon the observation of its consequences) have had a strong impact even on administrative law. However, it would be an illusion to reduce the new discretionary power gained by reference to expertise to a mere delegation of power by parliament. ${ }^{123}$

\section{E. General Administrative LaW as the Product of Administrative Experimentation ... AND ITS JUDICIALISATION}

Upon the basis of the theoretical reflections given above, one should, first of all, bear in mind that administrative law could not and cannot be conceived of as being mainly a product of the legislator. The same is valid for private law. Both legal domains are characterised by the challenge of enabling processes to cope with the fundamental uncertainty and the dynamic of the self-transformation of society and to generate forms of binding them in order to allow for co-operation, co-ordination, and learning. Both the development of the administrative law of the "society of the individuals" and the successive administrative law of the "society of organisations" could only be the emergent product of primarily administrative experimentation and of the retention of successful forms of action ${ }^{124}$ including the increasing importance of procedure ${ }^{125}$ as a resource for the creation ${ }^{126}$ and combination of knowledge for decision-

\footnotetext{
${ }^{122}$ Burkard Wollenschläger, WISSENSGENERIERUNG IM VERFAHREN (2009).

${ }^{123}$ This is the view taken by Kenneth Bamberger, Regulation as Delegation: Private Firms, Decision Making and Accountability in the Administrative State, 56 DUKE LAW JOURNAL 377 (2006).

${ }^{124}$ See generally for the autonomy of administration Edward L. Rubin, It's Time to Make the Administrative Procedure Act Administrative, 89 CORNELL LAW REVIEW 95 (2002) (claiming that administrative law is too narrowly following the patterns of judicial decision making); in a German perspective Wolfgang Hoffmann-Riem, Die Eigenständigkeit der Verwaltung, in: GRUNDLAGEN DES VERWALTUNGSRECHTS, Vol. 1, § 10 No. 13 (Eberhard Schmidt- Aßmann \& Andreas Voßkuhle, eds., 2006); for the legitimation of administrative agencies, Hans-Heinrich Trute, Die Legitimation der Verwaltung, ibid., § 7, 307.

${ }^{125}$ The role of procedure in administrative law should not be regarded as an illegitimate "ersatz" for appropriate democratic hierarchical empowerment, it is a necessary component of a procedural rationality of decision making which has to meet the challenge of uncertainty, see also Daniel C. Esty, Good Governance at the Supranational Scale: Globalizing Administrative Law, 115 YALE LAW JOURNAL 1490 (2006).
} 
making processes. ${ }^{127}$ Both in the private industry and in public administration, the use of experience as the common societal knowledge basis was no longer sufficient. ${ }^{128}$ It is not by accident that, in a country such as Germany, since the early 1960s, a continuous process of broadening the scope of judicial control over the whole domain of the administration, which, in the past, had been reserved for non-legal administrative rationality (schools, status of public staff). ${ }^{129}$ In the same vein, discretion has been increasingly judicialised. ${ }^{130}$ As in the US, in Germany, too, there has been a permanent broadening of the acceptable arguments in legal controversies: more and more public decision-making is not only subject to strict control upon the basis of specific legal arguments, but also reference to the "principle of proportionality"131 or a broad understanding of constitutional liberties (which include "principles of protection" beyond the traditional conception of negative liberties) are commonplace today. This evolution is hailed by many as a phenomenon of "legalisation" of factual power. ${ }^{132}$ Upon closer inspection, this view appears to be superficial because it neglects the decline of the impact of the self-organised knowledge base and the set of social conventions which defined a collective understanding of a "common sake" of the public, ${ }_{133}$ while bargaining processes regarding the right of the individual upon an ad hoc basis have increasingly come to replace this collective element of the conventional infrastructure of the law as described above. This is, so to speak, the dark side of the change of paradigms in society: the emergent "society of organisations" tends to keep its rationality more or less invisible. Once self reflexive bargaining processes come into place which undermine the universalistic character of the liberal legal order, and the

\footnotetext{
${ }^{126}$ Lefebvre, supra, note 79,254 , for the creative role of legal decisions.

${ }^{127}$ For the U. S. administrative law in the $19^{\text {th }}$ century this autonomous role of administration and the creation of its own "internal law" is epitomised in Mashaw, supra, note 7; 1413, 1461.

${ }^{128}$ See for the evolution of the knowledge basis of public decision making Karl-Heinz Ladeur, The Postmodern Condition of Law and Societal Management of Rules. Facts and Norms Revisited, 27 ZEITSCHRIFT FÜR RECHTSSOZIOLOGIE 87 (2006).

${ }^{129}$ Again this does not differ much from the court restraint visa-vis administrative discretion in $19^{\text {th }}$ century, Mashaw, supra, note 127.

${ }^{130}$ See Elizabeth V. Foote, Statutory Interpretation or Public Administration: How Chevron Misconceives the Fuction of Agencies and Why it Matters, 59 ADMINISTRATIVE LAW REVIEW 673 (2007).

${ }^{131}$ Alec Stone Sweet \& Jud Mathews, Proportionality Balancing and Global Constitutionalism, 47 COLUMBIA JOURNAL OF TRANSNATIONAL LAW (2008), 72; Jacco Bomhoff, Genealogies of Balancing as Discourse, 4 LAW \& ETHICS OF HUMAN RIGHTS 108 (2010), available at http://www.bepress.com/lehr/vol4/iss1/art6; the principle has found a philosophical preparation in the German "materiale Wertethik" (Nicolai Hartmann and Max Scheler) which has attributed to the facticity of values a normative foundation in the subjective act of valuing, See Nicolai Hartmann, Das Wertproblem in der Philosophie der Gegenwart, in: KLEINERE SCHRIFTEN, 327 (1958), where the "type of situation" and its framing by the time of its emergence is regarded as essential for the attribution of values; Robert Spaemann, SCHRITTE ÜBER UNS HINAUS. GESAMMELTE REDEN UND AUFSÄTZE, VOL. I 90 (2010); for a critique see also Karl-Heinz Ladeur, Das Bundesverfassungsgericht als 'Bürgergericht'?, 31 RECHTSTHEORIE 267,76 (2000).

${ }^{132}$ For its development see Eric Engle, The History of the General Principle of Proportionality: An Overview, July 2009, available at ssrn.

${ }^{133}$ Myriam Revault d'Allonnes, LE POUVOIR DES COMMENCEMENTS. ESSAI SUR L'AUTORITÉ 59 et seq. (2006).
} 
borderline of the "no harm" principle ${ }^{134}$ loses its cognitive and normative function (for example, the attribution of personal responsibility) any interest might re-enter the procedure of rule-making and put the bindingness of law at risk. ${ }^{135}$

This decline is a repercussion of the emergence of a new paradigm of the legal infrastructure, i.e., the rise of the "society of organisations". ${ }^{136}$ Again. the focus here is not on the comprehensive re-construction of this new societal formation and the transformation of the legal system which it provokes. Instead, the focus will be on the change of the societal knowledge basis which is characterised by a split between, on the one hand, the continuity of the self-reproduction of general experience distributed over the whole of society, and, on the other, the advanced knowledge which is generated by the big organisations both in the economic and the broader sense (including political parties, unions etc.). ${ }^{137}$ This new type of technological knowledge in particular has a far-reaching impact on the laws concerning the protection of health and the environment, because they introduce a prospective strategy ("the precautionary principle", 138 "risk", instead of experience based "danger", the balancing of interests in planning law, etc. ${ }^{139}$ ). The differentiation of the new legal paradigm cannot be described in detail here. ${ }^{140}$ What is relevant for the intention of the present article is the hypothesis that both administrative action and judicial control change considerably - an assumption which does not rule out the continuity of the ongoing administrative practices of the past within a basic layer of decision-making on which a new layer of operations is superimposed It is structured by more complex and more sophisticated conventions and rules, which underlie a higher level of organised reflected observation, ${ }^{141}$ explicit formulation and revision:

\footnotetext{
${ }^{134}$ Nadia Urbinati, MILL ON DEMOCRACY: FROM THE ATHENIAN POLIS TO REPRESENTATIVE GOVERNMENT 211 (2002).

135 See also Ran Hirschl, TOWARDS JURISTOCRACY: THE ORIGINS AND CONSEQUENCES OF THE NEW CONSTITUTIONALISM 212 (2009), where the increasing juridification of political questions is correlated with the waning of confidence in technocratic governance: the judicial institutions replace the lessening integration of society by social norms.

${ }^{136}$ See only Ladeur, supra, note 128.

${ }^{137}$ Ladeur, supra, note 128.

${ }^{138}$ See only for the precautionary principle Nicolas de Sadeleer, ENVIRONMENTAL PRINCIPLES: FROM POLITICAL SLOGANS TO LEGAL RULES 174 (2005).

139 See Matthew Diller, The Revolution in Welfare Administration: Rules, Discretion and Entrepreneurial Government, 75 NEW YORK UNIVERSITY LAW REVIEW 1121 (2000).

${ }^{140}$ Karl-Heinz Ladeur, The Introduction of the Precautionary Principle into EC Law - A Pyrrhic Victory for Environmental and Public Health Law?, 40 COMMON MARKET LAW REVIEW 1455 (2003), and the critical commentary by Sebastian Wolf, Risk Regulation, Higher Rationality and the Death of Judicial Self-Restraint, 41 COMMON MARKET LAW REVIEW 1125 (2004).

${ }^{141}$ See Eyal Benvenisti, Reclaiming Democracy: The Strategic Uses of Foreign and International Law by National Courts, 102 AMERICAN JOURNAL OF INTERNATIONAL LAW 241, 260 (2008) for the problems related to the
} 
more and more implicit conventions which were co-ordinated and administered by large professional associations (VDI etc.) ${ }^{142}$ are replaced by explicit "standards" ${ }^{143}$, and by privatepublic organised decisions (in multiple forms). ${ }^{144}$ For the New Deal, it can be shown, as well, that the emergence of a new type of expertise-based administration, deference to a type of knowledge that originated from the organised processes of cognitive specialisation beyond the general level of distributed experience, led to a reduction of judicial control which was later on compensated ${ }^{145}$ - once the new structure had settled and was organised by a new paradigm by new approaches to a closer control of procedure, ${ }^{146}$ instead of the substance of decisionmaking. This shows that the participation of private parties in the regulatory process is inevitable ${ }^{147}$ and legitimate, as was the case in the private generation of experience in the "society of the individuals".

One can summarise this evolution with the words of Noonan, Sabel and Simon ${ }^{148}$ as a transfer from "rule orientation" to the "formulation of plans". This is, of course, a simplification, but it epitomises, with good arguments, the rise of a strategic component in both public and private decision-making: it is no longer the ideal of the continuity of the self-transformation of experience and the stability of public order which are both observed and preserved in a caseby-case mode via individual decisions ("acte administratif"). Instead, decisions increasingly have to be made in prospective "chains" of a plurality of actions both at the same time level (coordination of plans) and with a view to an increasingly uncertain future. This leads to more fragmentation within administration, an evolution which finds its expression in the rise of independent agencies in the US, in particular, or in a loosening of the inter-relationship between the processed singular decisions: the "administrative act" loses its role of coordination among single decisions, while, at the same time, the fragmentation and the pluralisation of the types of decision-making rises. The focus on the processing of single acts and administrative discretion, on the one hand, and the observation and stabilisation of internal rules and doctrinal focal points as frames of reference in the processing of decisions on

fragmentation of international environmental law: one way to deal with them consists in the reintegration of open principles of international law into the more elaborated structure of domestic environmental regulations.

${ }^{142}$ For the evolution see Wolf, supra, note 46 ; Več, supra, note 46.

${ }^{143}$ See the overview in Sabino Cassese, Global Standards for National Administrative Procedure, 68 LAW AND CONTEMPORARY PROBLEMS 109 (2005).

${ }^{144}$ See the contributions in INTEGRATING SCIENTIFIC EXPERTISE INTO REGULATORY DECISION-MAKING (Christian Joerges, Karl-Heinz Ladeur \& Ellen Vos, eds., 1997).

${ }^{145}$ Reuel Schiller, The Era of Deference: Courts, Expertise, and the Emergence of New Deal Administrative Law, 106 MICHIGAN LAW REVIEW 399 (2007).

${ }^{146}$ See in a political science perspective Mathew D. McCubbins, Roger G. Noll \& Barry R. Weingast, Administrative Procedures as Political Control, 3 JOURNAL OF LAW, BUSINESS AND ORGANIZATION 243, 257 (1987).

${ }^{147}$ See Michael P. Vandenbergh, The Private Life of Public Law, 105 COLUMBIA LAW REVIEW 229 (2005).

${ }^{148}$ Legal Accountability in the Service based Welfare State, Columbia Public Law Discussion Paper 08-162 
the other, vanishes and is replaced by the emergence of more loosely-coupled clusters ${ }^{149}$ and patterns of strategic comprehensive decision-making. ${ }^{150}$

The complexity of planning procedures, social insurance and social assistance, and the supervision of technologies which developed beyond the horizon of practical communities and led to the establishment of more professional communities of specific knowledge ("expertise") $)^{151}$ could primarily only be tackled by 0 administration itself and not by steering laws. ${ }^{152}$

\section{F. SOCIETY OF Networks AND the Networks Of LAW}

The rise of the "society of networks", 153 a kind of a tertiary remodelling of the "society of the individuals" is the next step within the evolution of administration: it is characterised in the cognitivist approach developed here by the reaction to a further rise in complexity of the knowledge base of society. This evolution is due to the fact that the structuring capabilities of the second order model of modern society is changed by the rise of a new mode of production and organisation (supported by the importance of information as the principal resource of production). The change to flat hierarchies ${ }^{154}$ and heterarchical self-organisation which process information in a new mode generates a third layer of the organisation of postmodern society. Technological knowledge, in particular, is no longer concentrated in stable expert communities, but is distributed in overlapping project-oriented "epistemic communities" which combine general and specific knowledge production in hybrid forms of communication; the primary examples are biotechnology, and computer technology both as a basis of production of new

\footnotetext{
${ }^{149}$ See for a conception of the cases of the U.S. Supreme Court as "nodes" within a network of interrelationships Timothy R. Johnson et al., Network Analysis and the Law: Measuring the Legal Importance of Supreme court Precedents, 15 POLICY ANALYSIS 324 (2007); in a similar vein David G. Post \& Michael B. Eisen, How Long is the Coast Line of the Law?. Thoughts on the Fractal Nature of Legal Systems, 29 JOURNAL OF LEGAL STUDIES 584 (2000).

150 See for a reference to the network (and related conceptions) Thomas A. Smith, The Web of Law, San Diego Legal Studies research Paper 06-11.

${ }^{151}$ See Philip E. Tetlock, EXPERT POLITICAL JUDGMENT: HOW GOOD IS IT? HOW CAN WE KNOW? 216 (2005).

152 This does of course not exclude a more dominant role of the judiciary which tends to second guess the rationality of administrative decision-making, Martin S. Shapiro, Juridicalization of Politics in the US, 15 INTERNATIONAL POLITICAL SCIENCE REVIEW 101, 107 (1994) (for the "litigation-oriented style of rulemaking").

153 See for a general theory Manuel Castells, THE RISE OF THE NETWORK SOCIETY: THE INFORMATION AGE. ECONOMY, SOCIETY AND CULTURE, Vol. $1,2^{\text {nd }}$ ed. (2000).

${ }^{154}$ Nico Krisch, The Pluralism of Global Administrative Law, 17 EUROPEAN JOURNAL OF INTERNATIONAL LAW 247 (2006); Paul Schiff Berman, From International Law to Globalization and Law, 43 COLUMBIA JOURNAL OF TRANSNATIONAL LAW 485 (2005).
} 
information programmes and as an organisational resource in other fields of production. ${ }^{155}$ More and more hybrid modes of organisation which blend forms of the market and organisational closure ("network contracts") $)^{156}$ spread in society, and have a repercussion on the procedures of administrative decision-making which transcend traditional borders and stable separations. This transformation is driven by a disruptive change of information technology and the ensuing modes of communication ${ }^{157}$ that easily transcend the hitherto established borderlines between organisations, organisational departments and allow, for example, for hybrid forms of co-operation between people who remain, in one respect, strong competitors. ${ }^{158}$

The rise of the concept of "governance"159 as a reflection of the transformation of the established "control projects" 160 is referred to in both the private and the public sector. For administration, this is equivalent to an even more intense involvement in knowledge generation processes, ${ }^{161}$ on the one hand, and the decrease of the privileged role of the "acte administratif" ("Verwaltungsakt") as the "signifier" ${ }^{162}$ for the processing of the interrelationships which allow for the weaving of knowledge-generating and knowledge-stabilising networks of decisions ${ }^{163}$ which bind uncertainty and allow for the linkage with private

\footnotetext{
${ }^{155}$ Michel Gensollen, Economie non rivale et communautés d'information, RÉSEAUX 141 No. 124 (2004),; id., Biens informationnels et communautés médiatisées, 113 REVUE D'ECONOMIE POLITIQUE, Special number, 8 (2003); see also Ladeur, supra, note 146.

${ }^{156}$ Gunther Teubner, NETZWERK ALS VERTRAGSVERBUND. VIRTUELLE UNTERNEHMEN, FRANCHISING, JUST-INTIME IN SOZIALWISSENSCHAFTLICHER UND JURISTISCHER HINSICHT (2004).

${ }^{157}$ Dirk Baecker, Systems, Network, and Culture, 15 SOZIALE SYSTEME 271, 272 (2009).

${ }^{158}$ For the trend toward network like organizations see Paul J. DiMaggio, Introduction: Making Sense of the Contemporaray Firm and Prefiguring its Future, 3, 5, 19, in: The TWENTY-FIRST CENTURY FIRM: CHANGING ECONOMIC ORGANIZATION IN INTERNATIONAL PERSPEKTIVE (id., ed., 2001).
}

${ }^{159}$ For the use of the concept of "governance" for a theory of administrative law in particular see Orly Lobel, The Renew Deal, 89 MINNESSOTA LAW REVIEW 263 (2004); for political science see Renate Mayntz, Governance Theory als fortentwickelte Steuerungstheorie, 11, in: GOVERNANCE-FORSCHUNG, (Gunnar Folke Schuppert, ed., 2005); Hans-Heinrich Trute, Wolfgang Denkhaus, Doris Kühlers, Governance in der Verwaltungsrechtswissenschaft 37 DIE VERWALTUNG 451, 456 (2004); for the change from regulation and public "steering" of market processes to the design of complex processes of public-private coordination; see also the contributions in: GOVERNMENT BY CONTRACT: OUTSOURCING AND AMERICAN DEMOCRACY (Jody Freeman \& Martha Minow eds., 2009) and KarlHeinz Ladeur, Keyword: International Governance, Theory of, in MAX PLANCK ENCYCLOPEDIA OF PUBLIC INTERNATIONAL LAW, to appear 2011.

${ }^{160}$ Harrison C. White, IDENTITY AND CONTROL. HOW SOCIAL FORMATIONS EMERGE, $2^{\text {nd }}$. ed., 220 et seq. (2008); id., Networks and Meaning: Styles and Switches, 13 SOZIALE SYSTEME 543 (2007); Dirk Baecker, WIRTSCHAFTSSOZIOLOGIE 128 (2006).

${ }^{161}$ This is why the explanation of the rise of the concept of "governance" as a repercussion of the subsumption of the state under the logic of the firm seems to be to simplistic, see Myriam Revault d'Allonnes, POURQUOI NOS N'AIMONS PAS LA DÉMOCRATIE 125 (2010).

${ }^{162}$ Yair Neuman, On Love, Hate and Knowledge, 90 INTERNATIONAL JOURNAL OF PSYCHOANALYSIS 697 (2009).

${ }^{163}$ See in a theoretical perspective on the paradigmatic structuring of intrapersonal networks of self-regulation, Neuman, ibid., 702. 
transactions. The relationship with private actors takes on an increasingly project-based orientation because it is the private sector which controls the knowledge processes in projectrelated networks as well. "Project", in this sense, is not equivalent to a goal-oriented process on the contrary, it refers more to a complex "mapping" of different co-operative ventures which are supposed to generate a domain of action first from which specific actions and strategies might emerge in an evolutionary way. ${ }^{164}$ Administrative networks of co-operation ${ }^{165}$ have to be set up both within the public sphere for the knowledge accumulation and outside it, i.e., via inter-relationships with networks of private actors. ${ }^{166}$ This is true for the support of technology (telecoms, high-tech) and also for the management of whatever risks which emerge from production processes which are set up beyond the realm of the traditional experiencebased knowledge production. It should be epitomised that the basic "change agents" which produce a new deep process of self-transformation within the legal system and its infrastructure of social norms ${ }^{167}$ and practices have a cognitive nature: i.e., the knowledge used in production processes and their management underlie a disruptive change, and shatter the paradigm of co-ordination among the different layers of the rule system of society. The rapid transfer of knowledge enabled by information technology undermines the conceptual, organisational, legal and practical separations upon which the legal system is based, such as the institutional separation of the market (exchange processes) and organisation (which keep production and management processes partially insulated from markets). The use of sophisticated information technology allows for the establishment of hybrid co-ordination processes which show characteristics of both hitherto separated forms of order: for example, complex contracts on the co-ordination of firms and their suppliers make a close integration of production processes possible without a formal integration. This is one of the phenomena of a new network-like forms of generating order between stable organisational hierarchy and heterarchical "loose" co-ordination via the market and contracts. A further element is to be seen in the closer connection between technology and science in the development of high-tech products and procedures: the established stable mode of co-ordination between general science and specific product development undergoes a transformation which leads to a much

164 For a theoretical perspective see Patrick Schumacher, Les mécanismes de l'innovation radicale, 85 COMMUNICATIONS No. 85, 171, 180 (2009).

${ }^{165}$ See for the transnational level Kal Raustiala, The Architecture of International Cooperation: Transgovernmental Networks and the Future of International Law, 43 VIRGINIA JOURNAL OF INTERNATIONAL LAW 1 (2002).

${ }^{166}$ For the characteristic element of transnational cooperation among "like" administrative agencies see ead. \& David Zaring, Networking Goes International: An Update, 2 ANNUAL REVIEW OF LAW \& SOCIAL SCIENCE 211, 215, 223 (2006).

167 See also Eric A. Posner, LAW AND SOCIAL NORMS 4 (2000) who points out that law operates alwa against a “ background stream of nonlegal regulation" - however, game theory may be to thin to do justice to the productivity of social normativity. 
closer reciprocal interrelationship between science and technology in both directions: ${ }^{168}$ i.e., on the one hand, joint-ventures on research of private firms react to the rapid transfer of scientific knowledge to product development (biotechnology). At the other extreme of the range of possibilities, one can observe even technological processes (Nano-technology) where there is no separation between these hitherto separated modes of knowledge and technological interventions into nature or the structure of materials creates new realities which lie beyond the abstract scientific observation of an outside reality. This need not be deepened here. ${ }^{169}$ At the middle range of technological evolution, the transformation of the network industries, in particular, have to be mentioned: the monopolistic hierarchical development of telecommunications services that followed a stable trajectory of technological improvement of "big networks" ${ }^{170}$ has been changed to a complex heterarchical opaque search process under extreme uncertainty. ${ }^{171}$ This development has had considerable repercussions in the transformation of the legal structure of regulation: the state no longer claims to occupy a privileged observing position, instead, its position has been shifted to the periphery of a heterarchical network whose development can only be anticipated in a scenario-like mode. ${ }^{172}$

\section{G. The Changing "Social Epistemology" of the LaW and the Fragmentation of Society}

The strategic "design" of such loosely-coupled networks is only imaginable as a co-operative venture in which the private actors have a stake themselves, because it pre-supposes the joint constructive contributions of more actors and information brokers, ${ }^{173}$ and includes the necessity to set up a self-reflexive component of a knowledge management: knowledge is not a neutral resource that can be conceived without paying attention to "social epistemology" as should have been made plausible by the examples of the knowledge basis of the "society of the individuals" and the "society of organisations". ${ }^{174}$ This reflection should have shown that the form of networks that is - with good reasons - invoked when it comes to the description of

\footnotetext{
${ }^{168}$ This is the case for nanotechnology Jean-Pierre Dupuy \& Alexei Grinbaum, Living with Uncertainty: Toward the Ongoing Normative Assessment of Nanotechnology, in: NANOTECHNOLOGY CHALLENGES: IMPLICATIONS FOR PHILOSOPHY, ETHICS AND SOCIETY 287 (Joachim Schummer \& Davis Baird, eds., 2006).

${ }^{169}$ See for the emergence of a conception of objectivity in natural science Lorraine Daston \& Peter Galiston, OBJECTIVITY (2007).

${ }^{170}$ Thomas P. Hughes, NETWORKS OF POWER: THE ELECTRIFICATION OF WESTERN SOCITIES 1880 - 1930 (1993).

${ }^{171}$ See in a theoretical perspective Herbert A. Simon, The Architecture of Complexity, PROCEEDINGS OF THE AMERICAN PHILOSOPHICAL SOCIETY Vol.1006, 467 (1962).

${ }^{172}$ Robert Baldwin \& Martin Cave, UNDERSTANDING REGULATION: THEORY, STRATEGY, AND PRACTICE, 31 (1999); see also Gunther Teubner, After Legal Instrumentalism? Strategic Models of Post-Regulatory Law, 299, in: DILEMMAS OF LAW IN THE WELFARE STATE (id., ed. 1986).

${ }^{173}$ Michael Stohl \& Cynthia Stohl, Human Rights, Nation States, and NGOs: Structural Holes and the Emergence of Global Regimes, 442, 72 COMMUNICATION MONOGRAPHS No. 4 (2005).

${ }^{174}$ Eileen M. Milner, MANAGING INFORMATION AND KNOWLEDGE IN THE PUBLIC SECTOR, 65, 164 et seq. (2000).
} 
administrative processes beyond the frames of territoriality ${ }^{175}$ is primarily a phenomenon which emerges from within the societal transformation of the nation states themselves. Global administrative law is not the product of the challenge of the state-based legal structure from outside, it is, instead, to be described as the outcome of a general shift from the paradigmatic forms of the "society of organisations" to the "society of networks", which has a disruptive effect on the legal structure which found a new stability in the 1970s and 1980s of the 20th century after a long period of experimentation. The emergence of the fragmented network form is due to a new evolutionary transformation of the knowledge- and rule-base of society in the broad sense sketched in this article. ${ }^{176}$

The rise of the concept of the network ${ }^{177}$ is a consequence of the fact that it is no longer a stable separation between the general experience as a distributed knowledge base, on the one hand, and the "best available" knowledge ${ }^{178}$ produced by big firms, on the other hand, which characterise the focal structure of the cognitive "pool of variety" but a much more heterarchically fragmented loosely-coupled cognitive network which is at stake in postmodernity. ${ }^{179}$ This new structure allows at the same time for more intense co-ordination among private actors themselves and between public and private actors in a way that blurs the hitherto-established separations that had already - if only to a limited extent - been severed by the institutions of the "society of the organisations". ${ }^{180}$ The flexibility draws on the fact that the phenomenon of the "joint venture" established by firms which still compete with each other on the market demonstrates the potential of co-operation in new project based "epistemic communities". ${ }^{181}$ This is valid both for the private and the public domain. In the realm of the

\footnotetext{
${ }^{175}$ For the fundamental transformation and flexibilisation of "space” see Saskia Sassen, TERRITORY, AUTHORITY, RIGHTS. FROM MEDIEVAL TO GLOBAL ASSEMBLAGES (2008); for the reconstruction of "space" as an outcome of complex formal and informal networks (as opposed to clear separation of "levels") see Kevin R. Cox, Spaces of Dependence, Spaces of Engagement and the Politics of Scale, 17 POLITICAL GEOGRAPHY 1 (1998).

${ }^{176}$ This transformation finds its repercussion in the rise of multiperspectivism in philosophy, in particular in Jacques Derrida, see Rodolphe Gasché, INVENTIONS OF DIFFFERENCE: ON JACQUES DERRIDA, 10, 61 et seq. (1994).

${ }^{177}$ See also Albert-László Barabási,LINKED. HOW EVERYTHING IS CONNECTED TO EVERYTHING ELSE AND WHAT IT MEANS FOR BUSINESS, SCIENCE AND EVERYDAY LIFE (2003); Veronika Tacke, Differenzierung und/oder Vernetzung? Über Spannungen, Annäherungspotentiale und systemtheoretische Fortsetzungsmöglichkeiten der Netzwerkdiskussion, 15 SOZIALE SYSTEME 243, 254 (2009).

${ }^{178}$ For the use of knowledge in economy still fundamental Friedrich August von Hayek, The Use of Knowledge in Society, 35 AMERICAN ECONOMIC REVIEW 519 (1945).

${ }^{179}$ For a "cognitivistic" approach to the regulation of global financial markets in particular See the contributions in: TOWARDS A COGNITIVE METHOD IN GLOBAL FINANCE. THE GOVERNANCE OF KNOWLEDGE-BASED FINANCIAL SYSTEM (Torsten Strulik \& Helmut Willke, eds., 2006); Torsten Strulik \& Matthias Kussin, Finanzmarktregulierung und Wissenspolitik. Basel II - Die aufsichtsrechtliche Konstitution kollektiver Intelligenz, 26 ZEITSCHRIFT FÜR RECHTSSOZIOLOGIE 101 (2005).

${ }^{180}$ Renate Mayntz, Modernization and the Logic of Interorganizational Design, 1 KNOWLEDGE \& POLICY 3 (1993).

${ }^{181}$ Gensollen, supra, note 155.
} 
latter, the state is able to co-ordinate its strategies with groups of firms in research processes which are no longer "steered" 182 by stable technological trajectories and expectations.

Something similar goes, for example, for the co-ordination among transnational firms upon the basis of the new Lex Mercatoria which is self-organised by private operators; however, one should bear in mind that, in general, rather big enterprises are parties like a "club", ${ }^{183}$ to its processing while conflicts among smaller firms are still judged by state courts with reference to a generalised set of norms which have their origin in the realm of public transactions. ${ }^{184}$

One has to admit that the cohesion of the new transnational law is (and can be) - to a much lesser extent - stabilised by public institutions; institutions (legal norms in particular): it is more driven by a network of dispersed strategic operations of big law firms (for transnational clients). This is not so much a non-democratic illegitimate form of law-making but, due to the advent of a new structural "drift" in the legal system, a phenomenon that is not new if we look back to the emergence of preceding legal paradigms. ${ }^{185}$

Looking back on the internal self-transformation of the state-based legal system, one can - with good reason - ask whether the ensuing fragmentation of the cognitive basis of the postmodern society and its impact on the fragmented legal system does not challenge the role of the public at large and its participation in legal rule-making. ${ }^{186}$ However, one has to be aware of the fact that, even in the liberal "society of the individuals", the central frame of reference for the generation of a collective order has been the spontaneously processed realm of experience and its societal rules, upon which the formal legal system was super-imposed as the second layer of the normative system of society. The legislator had only played a minor rule in this system as has been shown above. Even in the "society of organisations" during its heydays in the 1970s, the democratic "steering" potential of the state ${ }^{187}$ could not primarily make use of legislation, but, in the so-called "golden age", the nation state had to draw on the pre-structuring of society by the corporatist co-operation of the pluralistic social groups and the big firms and the

\footnotetext{
${ }^{182}$ See for the paradigm of "steering" private action through administrative law see Kersten \& Lenski, supra, at 9, 530 et seq.; Wolfgang Hoffmann-Riem, Eigenständigkeit der Verwaltung, in: GRUNDLAGEN DES VERWALTUNGSRECHTS, Vol. 1, § 10 No. 13 (Eberhard Schmidt-Aßmann \& Andreas Voßkuhle, eds., 2006).

${ }^{183}$ Esty, supra, note125, 1490; see also Alec Stone Sweet, The New Lex Mercatoria and Transnational Governance, 13 JOURNAL OF EUROPEAN PUBLIC POLICY 627 (2006).

${ }^{184}$ Monica Kilian, CISG and the Problem with Common Law Jurisdiction, 10 JOURNAL OF TRANSNATIONAL LAW \& POLICY 217, 226 (2001); Ingeborg Schwenzer \& Pascal Hachem, The CISG - Success and Pitfalls, 57 AMERICAN JOURNAL OF COMPARATIVE LAW 457 (2009).

185 See Sigrid Quack, Legal Professionals and Transnational Law-Making: A Case of Distributed Agency 14 ORGANIZATION 643, 644 (2007).

${ }^{186}$ For the legitimation function of participatory processes in decision making procedures see Esty, supra, note 125 , 1489.

${ }^{187}$ For this paradigm see David Y. Livshiz, Updating American Administrative Law: WTO, International Standards?, Domestic Implementation and Public Participation, 24 WISCONSON INTERNATIONAL LAW JOURNAL LAW 961 (2007).
} 
"representative organisations" of both. ${ }^{188}$ This complex group-based infrastructure of the late modern nation state has left its traces in the legal system, which was composed of both an increasing number of laws and the regulation of more and more spheres of societal domains in the welfare state. However, a closer look at the norms themselves make it clear that their conception pre-supposed a moderating role of administration and in the legal system in the proper sense a new methodology that opened itself toward the "normalising" impact of the differentiated social spheres by reference to broad concepts which built a bridge between the pre-structured reality and the law. A prominent example for this new methodology is the rise "balancing", and the "proportionality principle": ${ }^{189}$ both are fact ridden, in the same way as the understanding of the major concepts of liberal law had drawn on general experience and social norms ${ }^{190}$ as the frame of reference for the legal practice. The state-based conception of the democratic statute ${ }^{191}$ as the core of the legal system has always been normativistic wishful-

188 See Colin Crouch, CAPITALIST DIVERSITY AND CHANGE: RECOMBINANT GOVERNANCE AND INSTITUTIONAL
CHANGE 32, 92, 101 (2005).
189 See the overview in Tor-Inge Harbo, The Function of the Proportionality Principle in European Law, 16 EUROPEAN LAW JOURNAL 158 (2010); the "proportionality principle" can in my view not be interpreted as a judicial strategy to gain dominance over policy making or even the reform of constitution, as Alec Stone Sweet \& Jud Matthews, Proportionality Balancing and Global Constitutionalism, 47 COLUMBIA JOURNAL OF TRANSNATIONAL LAW 68 (2008), argue; this would be a much too broad assumption because this approach is often also chosen where courts could well follow more classical doctrinal strategies of argumentation (e. g. the judgments of the German Federal Constitutional Court on the constitutional limits of the freedom of expression or other constitutional liberties); even a rather politically active court such as this court is far from "dominating" policy making, it strengthens sometimes interests that are neglected by the consensus oriented political process but does not call its basis into question; reference to the proportionality principle is rather an expression of the increasing internal tensions within the postmodern legal order (Karl-Heinz Ladeur, KRITIK DER ABWÄGUNG IN DER GRUNDRECHTSDOGMATIK (2004) and its overcomplexity due to the openness to any interest and its lack of "metarules of collision"; see Andreas Fischer-Lescano \& Gunther Teubner, Regime-Collisions: The Vain Search for Legal Unity in the Fragmentation of Global Law, 25 MICHIGAN JOURNAL OF INTERNATIONAL LAW 1999 (2004); Robert Wai, Transnational Private Law and Private Ordering in a Contested Global Society, 46 HARVARD INTERNATIONAL LAW JOURNAL 471 (2005); and from a more pragmatic point of view Michelle Everson \& Christian Joerges, Reconceptualising Europeanisation as a Public Law of Collisions: Comitology, Agencies and an Interactive Public Adjudication, 512, in: Administrative Governance (Herwig C. Hofmann \& Alexander H. Türck ,eds., 2006). This means does not have a stable orientation as was the case in the liberal society of the individuals; Lucien Jaume, LA LIBERTE ET LA LOI 259, 304 (2000). The growing importance of constitutional control of the law and decision making processes in more and more countries is one of the many symptoms of the fragmentation of the legal system and its "entangled" hierarchies but not a consequence of a shift of law making power to courts. Hirschl , supra, note 135,214 , points out with good reasons that high courts only rarely call into question the established political power.

190 The focus on "social agents" as the main source of legal norms (and not the state as such) goes back to Philip Selznick, Philippe Nonet \& Howard M. Vollmer, LAW, SOCIETY AND INDUSTRIAL JUSTICE, 1969, 244.

191 In the US "democratic" legitimacy of administrative action historically was based more on the authority of the president than democratic statutes, see Jerry L. Mashaw, Administration and 'The Democracy': Administrative Law from Jackson to Lincoln 1829-1861, 117 YALE LAW JOURNAL1568 (2008). 
thinking. ${ }^{192}$ In this respect, no fundamental change has occurred in the postmodern society of the networks. This common limitation of legislation by its dependence on the "framing" effects of societal norms notwithstanding, the challenge to the legal system and its difficulties in finding a consistent response is undeniable. The question has to be re-formulated, though, in the sense of a search for a new role of the legal system in the stricter sense and a reformulation for the inter-relationships with the fragmented heterarchical type of looselycoupled norms generated from segmented functionally-specified networks, ${ }^{193}$ instead of rather stable group-based and organisation-based links between the law and the societal knowledge base. Both the law of the society of the individuals and the pluralistic law of the society of (representative) organisations ${ }^{194}$ were characterised by broad comprehensive cognitive "pools of variety" which corresponded to the territorial logic of the nation state, whereas the fragmented functionally-ordered segmented cognitive network of postmodernity lacks this focal orientation, which implies a potential transparency, of mutual interference and coordination by common meta-rules and methods of argumentation and comparison.

The common reference to the proportionality principle both in domestic and European law is problematical: because of its vagueness, it tends to block the adequate conceptualisation of new challenges related to the heterogeneity of postmodern law and its concomitant "norm collisions" ${ }^{195}$ It is only acceptable as a kind of "placeholder" for a new type of an emergent norm that is generated in an experimental mode ex post from the observation of new conflicts which cannot be solved with reference to traditional norms that are set ex ante and are "applied" to cases. This new type of norm which is generated "bottom up" is due to the high level of complexity of postmodern law.

The network like structure of the postmodern cognitive infrastructure is much less transparent and not easy to integrate into a comprehensive framework. This has an impact also on the selfunderstanding of citizenship which is not obviously compatible with the loose network of knowledge distributed not over society at large, but over differentiated webs which are not easily accessible to individuals, ${ }^{196}$ which take on a fragmented and self-designed character themselves. ${ }^{197}$

\footnotetext{
192 The authority of public institutions is derived from a complex "overarching governance structure" and not legislation alone, see Esty, supra, note125.

193 Niklas Luhmann, Die Paradoxien des Entscheidens, 17, 43, in: PARADOXIEN DER ENTSCHEIDUNG: WAHL/SELEKTION IN KUNST, LITERATUR UND MEDIEN (Friedrich Balke, \& Urs Stäheli, eds., 2003).

${ }^{194}$ Crouch, supra, note 184, p. 32.

195 Joerges \& Everson, supra, note 189; from the point of view of administrative law see Karl-Heinz Ladeur, The Significance of General Administrative Law for European Administrative Law, 167, in: Rainer Nickel (ed.), CONFLICT OF LAWS AND LAWS OF CONFLICT IN EUROPE AND BEYOND (Rainer Nickel, ed, 2010).

${ }^{196}$ Peter Fuchs, MODERNE KOMMUNIKATION 67 (1993).

${ }^{197}$ Ladeur, supra, note 128.
} 


\section{The Relationship BetWeen Administrative Agencies and Courts}

\section{A. The Co-Operative Construction of a Norm}

The focus on legitimacy and the simplistic supposition of a deductive rationality of the legal process detracts the attention from the problems of "internal autopoiesis" of law, i.e., the requirements of maintaining the closure of the system at the micro-scale, which Luhmann seems to neglect as well. ${ }^{198}$ The legal system can be regarded as being composed of chains of decisions being produced by the tribunals - this is what Luhmann calls the "centre" of the legal system, whereas the processing of contracts and other private transactions is to be located at the periphery. ${ }^{199}$ In my view, this rather static internal differentiation does not give sufficient tribute to the internal "unrest" which is continuously moving the system and which prevents its acentric processing from coming to a halt. ${ }^{200}$ The same is true for the conception of the legal system as composed of norms and their "application" to a case. Systems theory's focus on decisions and transactions comes closer to a more productive view of the internal aspect of the self-construction of the legal system. The legal system not only has to reproduce its border lines in order to close its rationality off from the direct interference of other systems (religion, politics) but it also has to reproduce its unity both by the flow of "legal components" (decisions, contracts, etc.) and by the reflection and control of the internal rationality of the interrelationships between operations: the process of decision-making or contracting cannot always start from zero, its internal experimentation has to weave connections between operations and to observe which patterns prove to be successful and which have to be "second guessed" in new trial and error processes. The functional requirement to stabilise expectations under conditions of uncertainty ${ }^{201}$ pre-supposes not only autonomy vis-à-vis the other social systems, but also the internal management of rules. Rules have a paradoxical character in as much as they cannot just preserve the "given" (in this case, one does not need rules in the modern sense), they have to allow for orientation in a society which is continuously involved in processes of self-transformation ${ }^{202}$ that includes the subject himself or herself, who "fulfils the mysterious function of association lived experience of the individual with a communicable and

\footnotetext{
${ }^{198}$ This seems true in spite of the fact that Luhmann takes into consideration that law is dependent on cases and is in search of a kind of "local' rationality" alone, Niklas Luhmann, supra, note 40, 352..

199 Luhmann, ibid., 293 et seq., 304.

200 See in a theoretical perspective on the discontinuity within the search processes of self-organization Henri Atlan, L'émergence du nouveau et du sens, 115, 122, in: L'AUTO-ORGANISATION. DE LA PYSIQUE AU POLITIQUE (PAUL DUMOUCHEL \& JEAN-PIERRE DUPUY, 1983): "random perturbations" may be self-reinforced and provoke the emergence of a new paradigm of "order from noise".

${ }^{201}$ Luhmann, ibid., 263 et seq.

202 This is why a the "paradoxical co-existence of legal and non-legal" has to be presupposed, Peer Zumbansen, Transnational Legal Pluralism, 1 TRANSNATIONAL LEGAL THEORY 141, 159 (2010).
} 
social form of expression". ${ }^{203}$ The rule has to be continuously re-worked and re-modelled ${ }^{204}$ by both new judgments and new operations as well as the generation of new patterns of public and private decision-making ${ }^{205}$ in order to be able to allow for co-ordination among individuals or other legal persons who have to struggle with the dynamics of self-transformation of society. This is why precedents (decisions) or patterns of contracting and a certain stability of expression guaranteed by referring to patterns of behaviour have to be reproduced by the legal system. The paradox of the decision is expressed quite convincingly by Russell Hardin, who takes the view that, in common law - not only there - the individual court decision is meant to produce a new rule for third persons, while the present litigants are simultaneously treated as though the rule had been in place when they acted". ${ }^{206}$ This includes the "docility" of the legal actors who have to adapt themselves to both factual and legal standards of behaviour. ${ }^{207}$ Against the background of these general assumptions, the concept of "network" may be helpful for the conceptualisation of the internal rationality of the legal system: this concept presupposes a complex infrastructure of the legal system and its internal inter-relationships which are managed and re-arranged by different forms of feedback loops. ${ }^{208}$ The feedback loops reinforce the connections between a cluster of operations which aggregate a "hub" and reproduce the closure of patterns of behaviour or a second order reflexive concept based upon the observation and justification of a pattern. At the same time, the network of patterned operations reproduces differentiation $i$. e., the separation between a pattern and a set of "exceptions" which are loosely-coupled with the pattern as a default mechanism which exerts a certain attraction on the acceptability of a certain construction, interpretation or argumentation in a legal process: ${ }^{209}$ for example, the freedom of a contract can, of course, always be called into question because "freedom" is a vague concept, but, in a traditional legal understanding, the possibility of bringing in this argument is kept separate from the pattern of normal contracting and restricted to invocation of mental illness, error, breach of boni mores, etc. This is not necessarily the case: the "hub which reproduces the pattern of a normal contract can be re-opened and the "structural hole", as network analysis might put the relationship between the stabilised "hub" and the weaker node of exceptional operations

\footnotetext{
${ }^{203}$ Neuman, supra, note 162, 705.

${ }^{204}$ See Sally Falk Moore, Law and Social Change: The Semi-Autonomous Social Field as an Appropriate Subject of Study, 7 LAW AND SOCIETY JOURNAL 719 (1973), who rightly underlines that the law is not an "entity capable of controlling that (social $-\mathrm{KHL}$ ) context".

${ }^{205}$ Kathleen Noonan, Charles F. Sabel \& William H. Simon, Legal Accountability in the Service-Based Welfare State: Lessons from Child Welfare Reform, 34 LAW \& SOCIAL INQUIRY 523, 524 (2006).

${ }^{206}$ Russell Hardin, INDETERMINACY AND SOCIETY 33, 47 (2003).

${ }^{207}$ For a theoretical perspective on the transsubjective character of procedures of standardisation as normalisation in the Foucauldian vein see Stéphane Legrand, LES NORMES CHEZ FOUCAULT, 2, 154 (2007); Macherey, supra, note 51, 81 et seq.; Albert Ogien, Du sens commun comme une sorte de faculté de juger, 445, in: NORMATIVITES DU SENS COMMUN (Claude Gauthier \& Sandra Laugier, eds., 2009.

${ }^{208}$ The transnational networks find their repercussion in the internal fragmentation of the nation state: Kenichi Ohmae, THE END OF THE NATION STATE: THE RISE OF REGIONAL ECONOMIES (1995).

${ }^{209}$ Lefebvre, supra, note 79, 59.
} 
which are kept separate in a smaller "hub", can be overcome by introducing new types of "weak" individuals for whom the pattern is modified (consumers, dependent workers and employees, etc). A new mode of overcoming this structural hole in private law is the reference to the constitution, i.e., an analogy is drawn between a private law operation and the infringement of a constitutional right by the state. ${ }^{210}$ This re-opens the internal closure which was established in the past and demands new forms of closure which limit this interrelationship in order to allow for stability within. The example shows that a completely patternless openness of the legal system to arguments would block the internal autopoiesis even if the outer autopoiesis was not at stake, because it could just be an orientation crisis of the legal system and not a case of interference of a different social system.

The past and present status of administrative law is not a creation of judges. Law in the administrative system is to be understood primarily as a self-generated set of rules by administrative deciders, which is controlled or shaped by the legislator or judges only after the fact. ${ }^{211}$ Judicial review can only be "sporadic and peripheral" ${ }^{212}$ A different picture would lead to "institutional blindness" 213 and ignorance of the creative and experimental function of administrators themselves and of the "wider conception of administrative justice" that includes the impact of the eigenrationality of administrative practices. ${ }^{214}$ It would also overtax the unity of administrative law. ${ }^{215}$

It is not by chance that, in Germany, the general rules of administrative procedure have only been codified in $1976 .{ }^{216}$ The above-mentioned complex processes enacted by the administration of the "society of organisations" have also been tackled at first by the administrative agencies themselves and have only been the object of vague laws which draw on the experience of administrators later on. Administrative law emerges from the indetermination of a process which draws on the decision as that which creates new experimental "bindingness" from situation to situation - in a society which is no longer based

\footnotetext{
${ }^{210}$ See the comparative contributions in: EUROPEAN AND US CONSTITUTIONALISM (Georg Nolte, ed., 2005).

${ }^{211}$ Thomas Poole, The Reformation of English Administrative Law, 68 CAMBRIDGE LAW JOURNAL 142, 155 (2009) 156; Jerry L. Mashaw, Between Facts and Norms: Agency Statutory Interpretation as an Autonomous Enterprise, 55 UNIVERSITY OF TORONTO LAW REVIEW 497, 520 (2005); id. supra, note 7, at 1378.

${ }^{212}$ Poole, ibid. 157.

${ }^{213}$ See generally Adrian Vermeule, JUDGING UNDER UNCERTAINTY: AN INSTITUTIONAL THEORY OF LEGAL INTERPRETATION (2006).

${ }^{214}$ Poole, ibid., 164, 167.

${ }^{215}$ Poole, ibid., 165.

${ }^{216}$ This is very similar to the evolution of American administrative law: the APA has mainly codified administrative practices, see Mashaw, supra, note 7;; for the political constellation that made possible the APA as a reaction to the New Deal see McCubbins, Noll \& Weingast, supra , note 146.
} 
upon the illusion of being able to reproduce a tradition - and not as deduced from a stable norm. ${ }^{217}$

This development, which was very similar in other countries such as France, UK, USA, is summarised by B. Kingsbury ${ }^{218}$ in the assumption that judges have, over time, been able to construct a system of administrative law without comprehensive specification in statutes or constitutional norms. The second part of this observation concerning the reduced involvement of the legislators is certainly correct. With the first part concerning judges, one might have difficulties, at least, as far as the "construction" of a system of administrative law is concerned. The main instrument of administrative law in France and Germany, the "administrative act", has long been regarded as a remnant of the absolutist state. However, as was remarked earlier, this is a one-sided observation: this institution has been completely remodelled and been adapted to the conditions of the liberal state and society: it allows for objectivation, selfcontinuation, learning and transparency. ${ }^{219}$ However, it remains a construction of administration; it has been recognised, structured and formalised by the judiciary. To call this "judge-made law" 220 is somewhat superficial, because it is more a product of a coupling between the networks of administration and the processing of a network of the judges which introduced stability (for the rights of individuals in particular) and specific rules for validity etc., into the administration law, although a major part of the rules relate to practices which have been generated by the administration itself. This true, in particular, for the broad range of administrative operations which are mainly self-referential, in the sense that the direct contact to the rights of the citizens is reduced or regarded as non-existent. In Germany, this is the world of the "special power relationships" ("besonderes Gewaltverhältnis") dominating public schools, military service, the status of civil servants and "public assistance", which implied a specific dynamic status allowing for administrative "creation", as opposed to public services provided by the state (such as the telephone, water, electricity, etc.) or local agencies, which could be the object of a special public law regime but did not impose a status of continuous regulation.

The claim to preserve a continuity of public order by administrative decision-making (administrative acts in particular) involved a leeway of discretion because rights were regarded from the outset as being inherently limited by the rights of others and the comprehensive "general interest" ${ }^{221}$ Notwithstanding this, this general interest was no longer that of the state,

\footnotetext{
${ }^{217}$ For a theoretical perspective on "indetermination" as the rule to which "perfect knowledge" is only the exception see Albert Ogien, LES RÈGLES DE LA PRATIQUE SOCIOLOGIQUE 109 (2007); Christiane Chauviré, PEIRCE ET LA SIGNIFICATION. INTRODUCTION À UNE LOGIQUE DU VAGUE (2007), both draw on Charles S. Peirce.

${ }^{218}$ Kingsbury, supra, note 9.

${ }^{219}$ For a critique see Mashaw, supra, note 9, 1378.

${ }^{220}$ See in a theoretical perspective Kerchove \& Ost, supra, note 14.

${ }^{221}$ See Bohlender, supra, note 49, for the evolution of the concept of "Gemeinwohl" ("common interest") in Germany.
} 
but of the "order" of society at large, which included - as mentioned before - continuous change. ${ }^{222}$

This phenomenon does not differ much from the relationship between private law in a stricter sense and the practical networks of experience which process the cognitive infrastructure of the law.

This is what is at stake when N. Luhmann ${ }^{223}$ regards "decisions" as the operation which is characteristic for the autopoietic process of reproduction of the legal system. One should go one step further and expand more on the idea of network as the infrastructure of the legal system. Luhmann himself also refers to the idea of network, but does not give much detail on what he means when referring to the phenomena of "networks" in the legal system. ${ }^{224}$ The shift from the hierarchical perspective on the legal norm as the steering element of the process of setting up the internal autopoietic structure of the legal system, to a heterarchical conception of the development based upon a processing of decisions not just from case-to-case but as a kind of management of inter-relationships and connection possibilities within a network of decisions, ${ }^{225}$ contracts and, above all, judgments might be more adequate as the reference to norms or "principles" as the "open source" of the legal system. Legal principles should not be regarded as being based upon the "nature of things" (G. Del Vecchio) or an abstract set of meta-rules for the generation and completion of norms, or their adaptation to specific cases. Instead, they are to be conceptualised as reflexive general experiences drawn from a vast amount of cases ${ }^{226}$ and linked to practices of legal decision-making. They have a distributed character themselves, in as much as they are processed within the networks as recurring patterns of the management of the inter-relationships and constraints which have been accumulated in the legal system. ${ }^{227}$ The autonomy of the legal system is not equivalent to being insulated from moral values, politics, economic interests, etc. Its autopoiesis consists, instead, in sustaining an impersonal "network of networks" of inter-relationships which generate patterns of operations, institutional constraints and beliefs (including the possibility of forming expectations and longer chains of actions) so as to make learning as a means of coping with uncertainty both possible and attractive. The autonomy of the legal system is a response

\footnotetext{
${ }^{222}$ Powell, supra, note 73.

${ }^{223}$ Luhmann, supra, note $198,46,78,98$, and passim.

224 Luhamnn, supra, note 193, 17, 43.; id., DIE GESELLSCHAFT DER GESELLSCHAFT, 65, 851 (1997), refers to the "networked" ("netzwerkförmig") interrelationships between communications and the generation of new opportunities for communication within systems; see also Tacke, supra, note 177.

${ }^{225}$ Luhmann, ibid., 17, 43.

${ }^{226}$ Luhmann, supra, note 198, 438.

${ }^{227}$ North et al., supra, note 60, 261.
} 
to the "essential incompleteness" ("inachèvement essentiel"228) of both individuals and society, which makes institutions the "engines of history" which retain a productive "pool of variety" of operations that shape change by imposing constraints, ${ }^{229}$ and allow for an impersonal monitoring upon the basis of a systemic memory. This distributed memory which is processed by the complex "network of networks" of cases and the internal rules on the reflection of interrelationships between cases and decisions allows for the "invention" of that which is not given a priori ${ }^{230}$ and generates new structured "regular" action potentials which, at the same time, open a perspective for co-operation, co-ordination, and repetition. Order cannot be generated from a privileged rational totalising view on society from "outside"; in a civil society, it is the emergent property of individual and organised productive operations with and within chaos, ${ }^{231}$ which is retained and structured by an institutionalised memory beyond the individual.

\section{B. The New Role of Judicial Control in Postmodern Societies}

As has been shown in this article, the breaks of symmetry in the technological system which challenge the network structure within the legal system are not managed by the legislator first, and are then broken down to a new practice of decision-making in the legal system. On the contrary, the constant flux of operations in the networks within the legal system and the exchange processes with the knowledge-producing networks outside are themselves the "agents of change". ${ }^{232}$ Apparently, the recent evolutionary transformations of administrative law are not well-reflected in legal theory, which tries to meet the challenge of complexity by new holistic approaches which abandon conceptual and doctrinal analysis of the change process.

German administrative law has been superseded in the last decades by a tendency to establish a monistic approach focused on rights ${ }^{233}$ and the proportionality principle. ${ }^{234}$ Interestingly, the same has been said recently about English administrative law, after the introduction of the European human rights into the English legal system. ${ }^{235}$ This is a reductionist perspective that

\footnotetext{
${ }^{228}$ Gauthier, supra, note 80, 242.

${ }^{229}$ North et al. , supra, note 60, 261; Greif, supra, note 98, 380.

${ }^{230}$ Gauthier, supra, note 80, 242.

${ }^{231}$ Gauthier, supra, note 80, 233.
}

232 See also the approach developed by Mashaw, supra, note 7, 1413, who also concentrates on practices of administrative agencies and not primarily its justification.

${ }^{233}$ The same can be said for constitutional law; this seems to be a general tendency in western law, see Mark V. Tushnet, The Rights Revolution in the Twentieth Century, 377, in: THE CAMBRIDGE HISTORY OF LAW IN AMERICA, Vol. 3, 337 et seq. (Michael Grossberg \& Christopher Tomlins, eds., 2008), (arguing that the concept of rights is shifting towards a broader understanding of the protection of "autonomy").

${ }^{234}$ See the references supra, note 189.

235 Poole, supra, note 211, 155; see also Richard B. Stewart, Administrative Law in the Twenty-First Century, 78 NEW YORK UNIVERSITY LAW REVIEW 437 (2003), who identifies different paradigms in American administrative law. 
ignores the complexity of the administrative tasks that cannot be accessed by a focus on the individual rights which are at stake in a decision-making process.

In global administrative law which is, in many respects, much more dependent on legitimation by state law in the stricter sense that the protagonists of a new look at a transnational legal sphere beyond the state tend to refer to general principles of $\operatorname{law}^{236}$ as - if not a source of legitimation - a limiting constraint, on the one hand, which serves as a legitimation basis, on the other hand. The role of these general principles remains rather unclear ${ }^{237}$ in modern legal theory, whereas, in more traditional approaches, the possibility of the deduction of such principles from the "nature of things" 238 is focused in a way which is no longer plausible today. This construction is another version of the ignorance of the necessary responsive cumulative mode of law-making inherent in administrative processes of decision-making. ${ }^{239}$

The recent evolution of new complex types of procedure and decision-making has had a strong impact on the coordination of administrative and judicial decision-making (and on the legislator, as well). Reference to the more structured and reflexive types of knowledge needs more procedural rules which re-construct the informational infrastructure of complex decisionmaking processes, ${ }^{240}$ instead of the more substantive, rule-based type of decision of the society of the individuals of the past. It should be born in mind that "rule-based", in the sense intended here includes all the layers or the normative and cognitive rules and conventions which are processed by reference to the individual right in the "private law society" and the single "administrative acts" of public administration which follow a similar logic, despite the seemingly sharp difference between public and private law. A similar evolution can be observed in private law, as well. This is, above all, true for tort law and liability for negligence, in particular.

\footnotetext{
${ }^{236}$ Tarcisio Gazzini, General Principles of Law in the Field of Foreign Investment, 10 JOURNAL OF WORLD INVESTMENT AND TRADE 1 (2009); Axel Metzger, EXTRA LEGEM, INTRA IUS: ALLGEMEINE RECHTSGRUNDSÄTZE IM EUROPÄISCHEN PRIVATRECHT 483, 519 (2009).

${ }^{237}$ A perspective which is more focused on the creative and generative elements of an autonomous legal system and its emergent character would lead to a procedural approach which regards general principles of law as a secondary layer of reflection of the inherent "unrest" of a system which is implied in a continuous process of selftransformation, see in this respect Metzger, ibid., 545 et seq.

${ }^{238}$ Giorgio del Vecchio, GENERAL PRINCIPLES OF LAW, 10 (1956); for a critique see Luhmann, supra, note 198, , 418.

${ }^{239}$ Mashaw, supra, note 7, 1476,

240 Thomas Vesting, Die Bedeutung von Information und Kommunikation für die verwaltungsrechtliche Systembildung, in: GRUNDLAGEN DES VERWALTUNGSRECHTS, vol. 2, supra, note 108, § 20 No. 1.
} 
With reference to court practice, the co-ordination between administration and judicial control becomes much more complex, ${ }^{241}$ as well. Whereas judicial control of administrative acts in the "society of individuals" could be focused on the doctrinal construction, variation and preservation of rules and mediating doctrinal inter-relationships between cases and decisions, judicial control of the administrative decision-making in the "society of networks" is much more complicated: one could re-conceive it more as a "web" or a network of judgments which revolve around a cluster of cases, ${ }^{242}$ and process information and orientation to administration in a more diffuse way. ${ }^{243}$ This evolution can lead to a more politicised control, ${ }^{244}$ both in a positive sense as an attempt by courts to set the substantive standards under conditions of uncertainty, or in the negative sense of leaving more room to administrative discretion, or it has to be re-considered and re-framed in a new way. As in the past, ${ }^{245}$ however, the steering function of the law and of the statutes, in particular, should not be over-estimated: ${ }^{246}$ the deliberation of this question should not be focused in a one-sided way on the legislator assuming a delegation of discretion enshrined in a statute where no such thing is to be found. Instead, a parallel should be drawn to the relationship between the law and its cognitive infrastructure in the "society of individuals": administration can no longer be oriented by the distributed sets of experience; instead, it draws on a multiplicity of self-organised societal knowledge types including self-generated "best practices", ${ }^{247}$ which stand for the innovative dimension of experimental future-oriented administrative action under conditions of uncertainty. ${ }^{248}$

${ }^{241}$ Carol Harlow \& Richard Rawlings, LAW AND ADMINISTRATION. LAW IN CONTEXT, $3^{\text {rd }}$ ed., 711 (2009); Armin von Bogdandy, GUBERNATIVE RECHTSETZUNG 368 (1999).

${ }^{242}$ Michael. J. Bommarito,II, Daniel M. Katz \& Jon Zelner, Law as Seamless Web, in: PROCEEDINGS OF $12^{\text {TH }}$ INTERNATIONAL CONFERENCE ON ARTICIAL INTELLIGENCE AND LAW, available at http://ssrn.com/abstract=1419525

${ }^{243}$ Thomas J. Miles \& Cass R. Sunstein, Depoliticizing Administrative Law, University of Chicago Public Law Working Paper 223 (June 2008), ; for a critique Peter L. Strauss, Overseers or Deciders: The Courts in Administrative Law, 75 UNIVERSITY OF CHICAGO LAW REVIEW 815 (2008).

${ }^{244}$ Miles \& Sunstein, ibid.

${ }^{245}$ For the changing conception of the relationship between (active) administrative regulation and the judicial control in history see Foster H. Sherwood, Judicial Control of Administrative Discretion 1932 - 1952, 6 THE WESTERN POLITICAL QUARTERLY 730 (1953).

${ }^{246}$ The ambiguity of the role of courts in complex cases of controlling administrative behaviour is a big issue in recent literature, see Strauss, supra, note 243, 815; Kenneth A. Bamberger \& id, Chevron's Two Steps, 95 VIRGINIA LAW REVIEW 611, 621 (2009): should courts act as guides for future administrative decision making procedures or rather respect the creative function of administration? See for the creative role of administrative agencies Dorit Rubinstein Reiss, Administrative Agencies as Creators of Administrative Law Norms: Evidence from the UK, France and Sweden, in: COMPARATIVE ADMINISTRATIVE LAW, 2010 (Susan Rose-Ackerman \& Peter Lindseth, eds., to appear).

${ }^{247}$ See generally David Zaring, Best Practices, 81 NEW YORK UNIVERSITY LAW REVIEW 294 (2006);

${ }^{248}$ The OECD plays also an important role in the search for transnational benchmarks Markku Lehtonen, OECD Benchmarking in Enhancing Policy Convergence. Harmonisation, Imposition and Diffusion Through the Environmental Performance Reviews, Ms. (2005). 
The focus of control should as a consequence shift to a more network like mode, i.e., the rules for administrative decision-making in complex domains, planning law, environmental ${ }^{249}$ or hightechnology law, or other types of strategic goal-oriented ways which comprise chains and networks of operations. The frame of reference for judicial control cannot be stable conceptions of the norm, individual rights, experience or doctrinal concepts, but, instead, the administrative decision-making process has to be formulated in a more comprehensive open way with a view to the limitations set by the challenge of action under conditions of uncertainty. As a consequence, the "control-project" 250 should also be formulated in a more open way, which is focused more on the outside observation (with a view to administration) of the plurality of network like inter-relationships between the different steps of the decisionmaking process on the one hand, and the potential concatenation of several decisions on the same time-scale and with a view to potential future administrative operations. This means that, instead of the orientation on the "substantive rationality" ${ }^{251}$ of rules whose structures and goals can, more or less clearly, be pre-supposed, the "procedural rationality" of both the distributed network of administrative ${ }^{252}$ and the judicial decisions should be considered with regard to the learning of new practices. ${ }^{253}$ With Dorf \& Sabel, one could talk about distributed practices of "experimentalism", ${ }^{254}$ which as I would like to add, replace or supplement

\footnotetext{
249 Ladeur, supra, note 82.

${ }^{250}$ See White, supra, note 160, 220.

${ }^{251}$ Herbert A. Simon, From Substantive to Procedural Rationality,129, in: METHOD AN APPRAISAL IN ECONOMICS, (Spiro J. Latsis, ed., 1976).
}

252 Kingsbury, Krisch \& Stewart, supra, note 1, 20; see also Benedict Kingsbury, Omnilateralism and Partial International Communities: Contributions of the Emerging Global Administrative Law, 104 JOURNAL OF INTERNATIONALLAW AND DIPLOMACY 98 (2005); Eleanor D. Kinney, The Emerging Field of International Administrative Law: It's Content and Potential, 54 ADMINISTRATIVE LAW REVIEW 415 (2002); Armin von Bogdandy, General Principles of International Public Authority: Sketching a Research Field, in: 9 GERMAN LAW JOURNAL 1909 (2008). $\quad$ http://www.germanlawjournal.com/pdf/Vol09No11/PDF Vol 09 No 11_1909-

1938 Articles von\%20Bogdandy.pdf; for the terminology see Susan Marks, Naming Global Administrative Law, 37 NEW YORK UNIVERSITY JOURNAL OF INTERNATIONAL LAW AND POLITICS 995 (2006).

253 John S. Brown/Paul Duguid, Organizational Learning and Communities of Practice: Towards a Unified View of Working, Learning and Innovation, 2 ORGANIZATION SCIENCE 40 (1991); Frédéric Creplet, Olivier Dupouet, Francis Kern, Babak Mehmanpazir \& Francis Munier, Consultants and Experts in Management Consulting Firms, 30 RESEARCH POLICY 1517 (2001), id., Technology Policy in the Kowledge-Based Economy, 75, 100, in: INNOVATION POLICY IN A KNOWLEDGE-BASED ECONOMY (Patrick Llerena \& Mireille Matt, eds., 2005); Patrick Cohendet, Knowing Communities in Organizations, in: ADVANCING KNOWLEDGE AND THE KNOWLEDGE ECONOMY 91,93 (Brian Kahin \& Dominique Foray, eds., 2006).

${ }^{254}$ See Michael C. Dorf and Charles F. Sabel, A Constitution of Democratic Experimentalism, 98 COLUMBIA LAW REVIEW 267, 314 (1998). See generally Charles F. Sabel and Jonathan Zeitlin, Learning from Difference: The New Architecture of Experimentalist Governance in the European Union, European Governance, Paper No C-07-02 (May 10, 2007), available online at <http://www.connex-network.org/eurogov/pdf/ egp-connex-C-07-02.pdf > ; Abbott \& Snidal, supra, note, 2009, 43.; for the democratic potential of open cooperation see Errol Meidinger, Competitive Supra-governmental Regulation: How Could it be Democratic?, 8 CHICAGO JOURNAL OF INTERNATIONAL LAW 513 
distributed experience as a core element of the infrastructure of the law. The relationship between administration and judicial control could be phrased as "tangled web", ${ }^{255}$ instead of as a stable rule-orientation, as might seem adequate for the "society of the individuals". As Joanne Scott and Susan P. Sturm ${ }^{256}$ have luckily formulated, one might regard the role of the judiciary in this tangled web of decisions somewhat as a "catalyst" which functions as "enabling", blocking or setting conditions of new actions under conditions of uncertainty, and uses the interference in the administrative process rather as a monitoring function thereby strengthening the internal rationality and transparency ${ }^{257}$ of the informational process and the learning capabilities in the future. ${ }^{258}$ At the same time, the judicial system should consider whether its own learning capabilities can be improved and stabilised by considering the productive concatenation of a new judgment with the requirements formulated in former decisions, and with a potential new judgment the future. In the analysis of judicial decisionmaking, reference has already been made to the distributed rationality of a network of judgments which have to be read in a horizontal heterarchical mode of processing from case to case. ${ }^{259}$ This approach should not be read as a support for individualised situative decisionmaking, not at all. There has to be a flexible concatenation which allows for the creation of reflexive web of "similar" judgments that tries to learn from the practical response of actors to its previous "entries" in the network of judgments. This institutional arrangement is a kind of "judicial polycentricity" 260 that corresponds to the polycentric processing of markets and its

(2008); ; on the responsibility of transnational governance networks see James Bohman, DEMOCRACY ACROSS BORDERS. FROM DÊMOS TO DÊMOI, 2010, 44 seq.; Anne-Marie Slaughter, Global Government Networks, Global Information Agencies, and Disaggregated Democracy, 121, in: PUBLIC GOVERNANCE IN THE AGE OF GLOBALIZATION (Karl-Heinz Ladeur, ed., 2004); Karl-Heinz Ladeur, Globalization and the Conversion of Democracy to Polycentric Networks: Can Democracy Survive the End of the Nation State?, ibid., 87.

255 Harlow \& Rawlings, supra, note 241, 711; Bommarito et. al., supra, note 242, epitomize the role of the "interconnectedness" of court decisions.

${ }^{256}$ Courts as Catalysts: Rethinking the Judicial Role in New Governance, 13 COLUMBIA JOURNAL OF EUROPEAN LAW 565 (2007).

${ }^{257}$ Esty, supra, note 125.

${ }^{258}$ See on the meaning of learning of general administrative law in jurisprudence, Carol Harlow, Changing the Mindset: The Place of Theory in English Administrative Law, 14 OXFORD JOURNAL OF LEGAL STUDIES 419 (1994); on learning through the development of "ordering ideas", in the exchange between general and particular administrative law, Eberhard Schmidt-Aßmann \& Stéphanie Dagron, Deutsches und französisches Verwaltungsrecht im Vergleich ihrer Ordnungsideen, 45 ZEITSCHRIFT FÜR AUSLÄNDISCHES ÖFFENTLICHES UND VÖLKERRECHT 395 (2007).

${ }^{259}$ See in a theoretical perspective on the concept of network as a paradigm of conceptual construction Seth J. Chandler, The Network structure of Supreme Court Jurisprudence, University of Houston Law Center No. 2005-W01..

${ }^{260}$ See Paul Dragos Aligica \& Peter J. Boettke, CHALLENGING INSTITUTIONAL ANALYSIS AND DEVELOPMENT. THE BLOOMINGTON SCHOOL, 26 et seq., 63 (2009); see also Robert Cover, 30, in: PROCEDURE (id., Owen Fiss, \& Judith Resnick, eds., 1988). 
administrative observation and limitation ${ }^{261}$ (in the past with the help of the "actes administratifs" in particular).

The network based approach ${ }^{262}$ developed here would assume that there is also a process of coupling between the practical networks of administrative decision-making and the private processes of contracting or arguing about the limits of rights (damage, negligence, etc. ${ }^{263}$ ) on the one hand, and the networks of court judgments which have to cope with the internal requirements of preserving consistency and the external requirement of keeping the practical networks of administration and private actors (in private law) productive and dynamic - this includes the respect for private autonomy in private law and discretion in public law, on the other. Robert Cover has regarded "jurisdictional redundancy" as a flexible strategy of avoiding errors. ${ }^{264}$ This idea is not to be confined to the plurality of courts in federal systems alone, but it should include the polycentric web of judgments that try to generate and manage the "density of experience". ${ }^{265}$ Methodological "dissensus" ${ }^{266}$ can also be regarded as a productive element in a more experimental search for new rules and patterns of co-ordination in both private an public law as long as a web-like structure of mutual reference, reflection, and revision is preserved with a view to the proactive generation of a common frame of judgment that loosely integrates a practice which is taken seriously.

\section{A Comparative look at the Network Like Structure of Transnational Court Practice in the Field of (Private) MEdia LAW IN PARTICULAR}

A closer look at Lex Mercatoria or the other private legal regimes shows that they have formed a new legal order for a network of (regular) participants, transnational economic and legal transactions in particular, ${ }^{267}$ which does not cover the whole of the arena of transnational

\footnotetext{
${ }^{261}$ At the same time there seems to be a structural limit to the intervention of courts into polycentric publicprivate networks, Noonan, Sabel \& Simon, supra, note 205, 559.

${ }^{262}$ For an Overview of the new relationship between systems theory and the new concepts of "network" see Tacke, supra, note 177, 243.

263 Kenneth S. Abraham, Custom, Noncustomary Practice, and Negligence, 109 COLUMBIA LAW REVIEW 1784 at 1796 (2009).

${ }^{264}$ Cover, supra, note $260,30$.

${ }^{265}$ Cover, ibid., 30.

${ }^{266}$ See Ethan J. Leib \& Michael Serota, Feature Essay: The Costs of Consensus in Statutory Construction, YALE LAW JOURNAL online, www.yalelawjournal.org, July $30^{\text {th }}$ 2010; this article is a critique of Abbe R. Gluck, The States as Laboratories of Statutory Interpretation: Methodological Consensus and the New Modified Textualism, 119 YALE LAW JOURNAL 1750 (2010).

${ }^{267}$ Teubner, supra, note 17.
} 
exchange. $^{268}$ The bearers of this network of law are (in private law) big firms, which continuously engage in an exchange of roles (they act both as sellers/providers and as buyers). This engagement is the basis for the emergence of common interests which are shared by transnational corporate actors in particular. At the other end of the range of action formats in transnational affairs, we must not forget the smaller- and medium-sized firms (SMEs) which only rarely engage in transnational transactions or the role of consumers. In this field, transnational contracts are still judged in cases of conflict by state courts. And it seems to be far from simple to develop a homogeneous stable court practice even upon the basis of a uniform legal text such as the Convention on International Sale of Goods (CISG) $)^{269}$ and in spite of a duty imposed on courts to consider the common interest in a homogeneous legal practice. ${ }^{270}$ The networking ${ }^{271}$ in this latter case is done by courts and not by the participants in transactional legal affairs, as in the field of Lex Mercatoria. This seems to be a common denominator which might be productive in conceptualising global law - public and private: The emergence of a global type of law "beyond the state" pre-supposes a network based common interest of participants, ${ }^{272}$ which is not identical with the public interest of an overarching community. This does not, from the outset, speak against the recognition of a new type of global law - far from it. It should, perhaps, warn us not to regard this phenomenon as just a transitory momentum which, in the long run, ends up in the "constitutionalised" world society. ${ }^{273}$ It would be

${ }^{268}$ For the rise of self-regulation of private actors see Virginia Haufler, Globalization and Industry Self-regulation, 226, in: GOVERNANCE IN A GLOBAL ECONOMY (Miles Kahler \& David A. Lake, eds., 2003); Peter Gourevitch, Corporate Governance: Global Markets, National Politics, ibid., 305.

${ }^{269}$ Schwenzer \& Hachem, supra, note 184, 468: who point out that the duty to refer to foreign judgments is no equivalent to the integrative function of a common supreme court.

${ }^{270}$ Kilian, supra, note 184; Schwenzer \& Hachem, ibid.

${ }^{271}$ The "network" concept is often used in a loose way; it should specified with respect to "some combination of informality, equality, and commitment" Paul DiMaggio, Conclusion: The Futures of Business Organization and Paradoxes of Change, in: id. (ed.), supra, note 158, 212 - I would add its functionality for a mode of generation of knowledge and management of uncertainty; see for the concept of the "disaggregated State" Anne Marie Slaughter, A NEW WORLD ORDER (2004); see also the contributions in: Ino Augsberg, Tobias Gostomzyk \& Lars Viellechner, DENKEN IN NETZWERKEN (2009).

${ }^{272}$ See The examples in Michael S. Barr and Geoffrey P. Miller, Global Administrative Law: The View from Basel, 17 EUROPEAN JOURNAL OF INTERNATIONAL LAW 15 (2006) 15; Michael Livermore, Authority and Legitimacy in Global Governance: Deliberation, Institutional Differentiation, and the Codex Alimentarius, 81 NEW YORK UNIVERSITY LAW REVIEW 776 (2006); Gus Van Harten and Martin Loughlin, Investment Treaty Arbitration as a Species of Global Administrative Law, 17 EUROPEAN JOURNAL OF INTERNATIONAL LAW 121 (2006).

273 Deborah Cass, The Constitutionalization of the World Trade Organization: Legitimacy, Democracy, and Communityin the International Trading System (2005); Neil Walker, Constitutionalism in a New Key: The EU and the WTO, 31, in: The EU and the WTO: Legal and Constitutional Issues (Gráinne de Burca \& Joanne Scott, eds., 2001); Anne Peters, Compensatory Constitutionalism: The Function and Potential of Fundamental International Norms and Structures, 19 LEIDEN JOURNAL OF INTERNATIONAL LAW 579 (2006); David Dyzenhaus, The Rule of (Administrative) Law in International Law, 68 LAW \& CONTEMPORARY PROBLEMS, 127, 139 (2005); Euan MacDonald, The ,Emergence' of Global Administrative Law, 2007, www.iijl.org/GAL/documents/MacDonald.pdf; with reference to human rights in particular Ernst-Ulrich Petersmann, Time for a United Nations 'Global Compact' for Integrating Human Rights into the Law of Worldwide Organizations: Lessons from European Integration, 13 EUROPEAN JOURNAL OF INTERNATIONAL LAW 621, 631 (2002); Bardo Fassbender, The United Nations Charter As 
preferable to distinguish more reflexive mechanisms in the practice of self-organised rules, which would - following the conception of the inter-relationship between law and different forms of social convention -include also rules of a practice which implicitly also formulate considerations about the balancing of competing interests of parties which are not involved in the network itself.

This is the case, for example, in the media, which continuously experiment with new formats of a construction of reality as they have to observe not only "reality", but also the selftransformation of the "identity" of the recipients themselves. ${ }^{274}$ According to a more collective societal (and not only individualistic) understanding of civil rights, the freedom of the press, in particular, also comprises the autonomy of the press as a societal institution with the consequence that it implies the freedom to formulate and modulate conceptions of the public interest and modes of its "formatting". ${ }^{275}$ At the same time, this implies a distributed tentative mode of considering competing interests such as the privacy of media stars and politicians. ${ }^{276}$ The role of courts should protect these rights, of course, but, at the same time, this implies a respect for the whole network of media communication and the logic of its functioning: the protection of conflicting rights should be fine-tuned to the rules and conventions of the media and not ignore its autonomy also with regard to the re-formulation of its understanding of, for example, what the public realm is (European Court of Human Rights, ECHR). ${ }^{277}$ This means that the constraints set by competing rights have to be formulated by courts, instead from a heterarchical point of observation which would be focused on "re-entering" a constraint into

Constitution of the International Community, 36 COLUMBIA JOURNAL OF TRANSNATIONAL LAW 529 (1998); id., ,We the Peoples of the United Nations': Constituent Power and Constitutional Form in International Law, 269, in: THE PARADOX OF CONSTITUTIONALISM. CONSTITUENT POWER AND CONSTITUTIONAL FORM (Martin Loughlin \& Neil Walker, eds, 2007) and, for a broader approach not limited to the UN framework, see two articles by Erika de Wet, The International Constitutional Order, 55 INTERNATIONAL AND COMPARATIVE LAW QUARTERLY 51 (2006); epitomizing rather the difference between administrative and constitutionalist approaches to gobal law: Nico Krisch, The Pluralism of Global Administrative Law, 17 EUROPEAN JOURNAL OF INTERNATIONAL LAW 247,253 (2006); Esty, supra, note 125, 1490; for a differentiated view cf. also Sabino Cassese, Administrative Law Without the State? The Challenge of Global Regulation, 37 NEW YORK UNIVERSITY JOURNAL OF INTERNATIONAL LAW AND POLITICS 663 (2005).

${ }^{274}$ See also Daniel J. Solove, UNDERSTANDING PRIVACY (2008): the contradictory relationship between privacy and publicity is also a consequence of the shaky ground on which the evolution of the media takes place.

${ }^{275}$ Karl-Heinz Ladeur, DAS MEDIENRECHT UND DIE ÖKONOMIE DER AUFMERKSAMKEIT (2007).

${ }^{276}$ See for the relationship between protection of substantive rights of individuals ("dignity") and a more formal process of public controversy James Q. Whitman, 'Human Dignity' in Europe and the United States, the Social Foundations, 108, in: Nolte (ed.), supra, note 210, 108.

${ }^{277}$ See with reference to the European judgments on the status of religion in public (schools) Ino Augsberg \& Kai Engelbrecht, Staatlicher Gebrauch religiöser Symbole im Licht der Europäischen Menschenrechtskonvention, 65 JURISTENZEITUNG 450 (2010), who demonstrate the difficulties European courts have in managing the cultural pluralism in Europe. 
the network for a re-modelling which bears in mind the procedural rationality which epitomises the rules and requirements of processing information under conditions of uncertainty ${ }^{278}$ and not to be blinded by traditional substantive rule orientation. ${ }^{279}$ This means that courts, instead, fulfil the role of oversight which should try to irritate the self-organisational potential of the media network in order to broaden the productive range of possibilities of reaction of the media system and not focus on a case-to-case-based substantial rationality of stable rules. ${ }^{280}$ The same is true for other private net-based communication such as the ebay ${ }^{281}$ valuation system, or ICANN, ${ }^{282}$ a system with its own private formal organisation which also has to find a balance between conflicting rights and interests. These examples could be counted as versions of self-organisation which need a certain public oversight because of the involvement of outsiders who cannot participate in the process of generating self-organised rules. ${ }^{283}$ This is not so unusual if one considers even the traditional experience-based rules, which courts refer to when deciding on "negligence" 284 or the preservation of the public order. The only major difference is to be seen in the fact that experience is more or less a spontaneously generated set of practical rules which has developed only a thin institutional layer in some fields (associations of engineers, etc.), whereas, in the case of a differentiated self-reflexive potential

${ }^{278}$ This is true in particular for transnational law See Cinto Della Cananea, Beyond the Stae: the Europeanization and Globalization of Procedural Administrative Law, 9 EUROPEAN PUBLIC LAW 563 (2003).

${ }^{279}$ This problematique includes also the evaluation of scientific uncertainty, see Stephanie Tai, Uncertainty About Uncertainty: The Impact of Judicial Decisions on Assessing Scientific Uncertainty, University of Wisconsin, SSRN; Karl-Heinz Ladeur, The Role of Contracts and Networks in Public Governance: The Importance of the 'Social Epistemology' of Decision Making, 14 INDIANA JOURNAL OF GLOBAL LEGAL STUDIES 329 (2007).

${ }^{280}$ James Q. Whitman, supra, note 276.

${ }^{281}$ Karl-Heinz Ladeur, EBAY-Bewertungssystem und staatlicher Rechtsschutz von Persönlichkeitsrechten, 10 KOMMUNIKATION \& RECHT 85 (2007).

${ }^{282}$ Milton L. Mueller, John Mathiason \& Hans Klein, The Internet and Global Governance:Principles and Norms for a New Regime, 13 GLOBAL GOVERNANCE 237 (2007); see for the tension between domestic legal principles and the self organized global ICANN regulatory regime Michael Froomkin, Wrong Turn in Cyberspace: Using ICANN to Route around the APA and the Constitution, 50 DUKE LAW JOURNAL 17, 57 et seq. (2000); Jonathan Zittrain, Between the Public and Private. Comments before Congress, 14 BERKELEY TECHNOLOGY LAW JOURNAL 1077 (1999); Jochen von Bernstorff, The Structural Limitations of Network Governance: ICANN as a Case in Point, 257, in: Christian Joerges, Inger-Johanne Sand \& Gunter Teubner (eds.), supra, note 105; Karl-Heinz Ladeur \& Lars Viellechner, Die transnationale Expansion staatlicher Grundrechte: Zur Konstitutionalisierung globaler Privaterchtsregimes, 46 ARCHIV DES VÖLKERRECHTS 42 (2008).

${ }^{283}$ Lawrence R. Helfer, Whither the UDRP: Autonomous, Americanized, or Cosmopolitan?, 12 CARDOZO JOURNAL OF INTERNATIONAL AND COMPARATIVE LAW 493 (2004); id. \& Graeme B. Dinwoodie, Designing Non-National Systems: the Case of Uniform Domain Name Dispute Resolution Policy, 43 WILLIAM AND MARY LAW REVIEW 141 (2001); Michael Froomkin, ICANN's «Uniform Dispute Resolution Policy» - Causes and (Partial) Cures, 67 BROOKLYN LAW REVIEW 605 (2002).

${ }^{284}$ Lefebvre, supra, note 79, 19; Gert Brüggemeier, HAFTUNGSRECHT. STRUKTUR, PRINZIPIEN, SCHUTZBEREICH 56 (2006); for the dependence of the concept of "negligence" on changing social norms See also Simon Deakin, Angus Johnston \& Basil Markesinis, MARKESINIS AND DEAKIN'S TORT LAW, $8^{\text {th }}$ ed., 113 (2008); Steven A. Hetcher, Creating Safe Social Norms in a Dangerous World, Vanderbilt Law School, Joe C. Davis Working Paper No. 995.(arguing that game theory misses the collective element of social norms in the process of concretizing negligence). 
of observation and revision of rules of practice to be followed by big firms (even below the level of formalisation in explicit standards ${ }^{285}$ ), the court has to consider the strategic effects of its decision-making practice in the search processes of the incumbent firms (duties to warn). These remarks should have demonstrated that private self-organisation and public oversight are not mutually exclusive. Law-making has always been process-driven, the institutionalised stable component used to be nested with the societal knowledge basis and with strategic action taken by legal practitioners. ${ }^{286}$

\section{After the experimental Creation of New Cooperative forms of} AdMINISTRATION... What? THE CODIFICATION?

The recent evolution of more complex administrative processes has raised interest in the internal procedures of generating information, knowledge, and evaluation of alternatives, etc. ${ }^{287}$ within the administration, which are no longer obvious, as was the case in the past. Administrative procedures of information as a side-effect of the increasing complexity of decision-making informal procedures ${ }^{288}$ of knowledge generation and forms of public- private co-operation ${ }^{289}$ (including contracting ${ }^{290}$ ) have been developed - again from within the administration. ${ }^{291}$ Approaches to establish a legal structure for this version of "co-operative

\footnotetext{
${ }^{285}$ See the contributions in: MULTILEVEL GOVERNANCE OF GLOBAL ENVIRONMENTAL CHANGE (Gerd Winter, ed., 2006); Martin Herberg, GLOBALISIERUNG UND PRIVATE SELBSTREGULIERUNG: UMWELTSCHUTZ IN MULTINATIONALEN UNTERNEHMEN (2007); also the contributions in: RESPONSIBLE BUSINESS. SELF-GOVERNANCE AND LAW IN TRANSNATIONAL ECONOMIC TRANSACTIONS (Olaf Dilling, Martin Herberg \& Gerd Winter, eds., 2008), in particular Errol Meidinger, Multi-Interest Self Governance through Global Product Certification Chains, ibid., 259.

${ }^{286}$ Quack, supra, note $185,643,644$

${ }^{287}$ Lisa Schultz Bressman, Procedures as Politics in Administrative Law, 107 COLUMBIA LAW REVIEW 1749 (2007) (emphasizing the role of courts to create acceptable rules for administrative agencies); for a critique that emphasizes the role of courts in the protection of rights as opposed to public policies see McNollgast \& Daniel B. Rodriguez, Administrative Law Agonists, 108 COLUMBIA LAW REVIEW, SIDEBAR 2008; see generally Stuart Shapiro \& David Guston, Procedural Control of the Bureaucracy, Peer Review, and Epistemic Drift, 17 JOURNAL OF PUBLIC ADMINISTRATION, RESEARCH \& THEORY 535 (2007); (underlining the dependency of conceptions of administrative control on the transformation of "embodied" knowledge).

${ }^{288}$ See for the difficulties to fit informal action into traditional legal administrative formats Kersten \& Lenski, supra, note $9,521$.

${ }^{289}$ See Errol Meidinger, The Administrative Law of Global Private-Public Regulation: the Case of Forestry, 17 EUROPEAN JOURNAL OF INTERNATIONAL LAW 47 (2006).

${ }^{290}$ See only Andreas Abegg, Die Vertragsfreiheit der Verwaltung - Verwaltungsverträge im Schatten des Rechts, 128 ZEITSCHRIFT FÜR SCHWEIZERISCHES RECHT 387 (2009).

${ }^{291}$ This development concept is related to the rise of the "governance", Lobel, supra, note 159.
} 
administration" 292 have failed hitherto. This is symptomatic for the relationship between the legislator and the administration: the major instruments of administrative action as such are beyond the reach of general regulation. This is due to the fact that the relationships between "public" and "private" 293 always contain an element of a "self-fulfilling prophecy": what is accepted as "regarding all" is an emergent property of entangled processes of the observation of practices and of paradigmatic settlements that are dependent on experiment. They can only be controlled on a case-to-case basis by the judges. The legislative form of rule-making is only compatible with administrative action if the networks of decision-making have developed contours - especially upon the basis of conflicting legal interests, subjective rights in particular. Notwithstanding this, this constellation is accessible only to a limited re-structuring by the legislator, which leaves enough potential for the shaping of different cases and the experimentation with different patterns of the management of inter-relationships.

The reflection on the evolution of modern law and its transformation during the 20th century have demonstrated the importance of the cognitive infrastructure of legal practice which has changed considerably, not only with regard to the character of the knowledge base itself upon which legal decision-making depends continuously. The law is not just super-imposed upon a cognitive base which allows it to be specified case-by-case, but the inter-relationship of both the cognitive and the normative layer of the law is not a passive one. The exchange is prestructured by secondary normalising meta-rules which stabilise the regularity of the process of reproduction of the "pool of variety" for different types of practices, and, at the same time, the law itself develops its own set of internal rules of interpretation, of estimating probabilities, proof rules in cases of non liquet, rules of presumption, of co-ordinating societal conventions and the legal rules in particular. ${ }^{294}$ In addition to this, there is an intermediate layer in which the role of the producers of the knowledge base is institutionalised (from public distributed knowledge accumulation) via organised reproduction in big firms towards postmodern network-like "epistemic communities" which provoke a fragmentation of the knowledge production. This transformation finds its repercussion in the shifting focus of the generation of

292 Gunnar Folke Schuppert, Verwaltungskooperationsrecht (Public Private Partnership): Regelungs- und Handlungsoptionen eines Rechtsrahmens für Public Private Partnership - Expertise for the Federal Minister of Internal Affairs, 2001, Attachment E (containing a proposal of an amendment to the Administrative Procedure Act); for the US See the proposal of a "Draft Collaborative Governance Executive Order", appendix to Lisa Blomgren Bingham, The Next Generation of Administrative Law: Building the Legal Infrastructure for Collaborative Governance, WISCONSIN LAW REVIEW 297 (2010) (the focus is on administrative values); the attempt to legalize and formalize cooperation is probably a misleading idea; see Freeman, supra, note 4 (1998), because it is a version of what one may call with Michael C. Dorf \& Charles F. Sabel, supra, note 254, 318: "democratic experimentalism" that does not allow for ex ante delegation of competencies and legislative formulation of goals; see in the same vein for American attempts to raise the level of transparency in new types of flexible administrative procedures, William Funk, Public Participation and Transparency in Administrative Law: Three Examples as an Object, 61 ADMINISTRATIVE LAW REVIEW 171 (2009).

\footnotetext{
${ }^{293}$ See Lobel, supra, note 159; Freeman, supra, note 4.

${ }^{294}$ See for the "internal law of administration" which is a necessary infrastructure of administrative operations and that is largely neglected or wryly looked at as being a type of non-law or illegitimate altogether Mashaw, supra, note 6, 1636; id., supra, note 7,1413, 1461.
} 
"order": from substantive rationality which supports the reproduction of rules to the management of conflicting group- and organisation-based knowledge by principles of balancing and the respect of proportionality - which are both open to the valuation of factual interests and positions - and finally the emergence of proceduralisation, ${ }^{295}$ which consists of an increasing importance of the proactive stimulation of the process of generation of knowledge in private and public networks. This change ends in a process of fragmentation of different arenas and allows only a loose mode of coupling between the differentiated networks by broad rules which are oriented at the open co-ordination of the tangled web of the law within a complex "network of networks". One should epitomise that the emergence of the "networks of law" in the postmodern society develops more and more different arenas for the construction of order in which the combination of cognitive and normative rules varies to a considerable extent. The close co-ordination in fragmented networks excludes outsiders, while, at the same time, the complexity and future orientation of the postmodern law reduces the protection granted in former times by "rights" ${ }^{296}$ because their frame of reference was, in the past (liberal society), also pre-structured by the general limitations imposed on subjective rights by other holders of rights: if the differentiation of the networks of operators increases, this will also change the general and universal frame of reference for the definition of the rules of co-ordination of rights of different subjects. At the same time, this evolution is - for the same reason - a challenge for the state, which loses its general frame of reference itself. The rules of co-ordination within the emerging "network of networks" of the law, which is much more loosely coupled than in the past, have not found their contours yet. This is why theoretical positions that question the legal character of the new self-organised norms which emerge in the differentiated range of rules that is characteristic of the postmodern normative "network of networks" miss the point: the increasing complexity of the cognitive embeddedness of legal norms demands a higher level of reflexivity of their mutual inter-dependence; a new constructive and selective dimension with regard to the fragmented cognitive rules and the construction of a whole domain of options (instead of the experimentation on a stable trajectory laid out by experience or the corporatist consensus based rules) has to be modelled. This is why the "internal" cognitive preparation of the administrative decision-making processes, which was more or less negligible in the outcome-oriented administrative law of the "society of individuals" has to be attributed normative character in different forms. This goes for administrative rule-making in the US, which uses "notice and comment"-procedures ${ }^{297}$ for the set up of enforcement rules which can no longer be derived from the law or be pre-supposed as the product of internal (administrative) or external (social) experience - for example, with regard to the societal

\footnotetext{
295 Karl-Heinz Ladeur, Proceduralisation and its Use in a Post-Modern Legal Policy, 53, in: GOVERNANCE IN THE EUROPEAN UNION (Olivier De Schutter et al., eds., 2001).

296 See for Germany Wolfgang Kahl, Über einige Pfade und Tendenzen in Verwaltungsrecht und Verwaltungswissenschaft - ein Zwischenbericht, 42 DIE VERWALTUNG 471, 473 (2009).

${ }^{297}$ Sean Farhang, THE LITIGATION STATE:PUBLIC REGULATION AND PRIVATE LAW SUITS, 21 (2010).
} 
approach to "danger". ${ }^{298}$ This is also the reason why more and more interests are transformed into rights to be heard, and to be protected from private or public interference below the level of the classical conception of "infringement" and "harm". ${ }^{299}$

This is a problematical side-effect of the fragmentation of the "networks of the law", ${ }^{300}$ which leads to a phenomenon which Sean Farhang ${ }^{301}$ has called the "litigation state": the courts are involved in a much more intense mode in the process of enforcement of legal norms. ${ }^{302}$ This is why the procedure and the reflection of the "internal" side of administration necessarily get a new normative dimension. The focus on the "publicness" of rules, or the search for a secondary layer of control of primary rules in the sense of H.L.A. Hart, ${ }^{303}$ misses this point, and it also transcends the horizon of H.L.A. Hart's conception of law. This increasing importance of the "internal side" of the processing of decision-making can also be observed in private law. Michael Power, in particular, has drawn our attention to this phenomenon: the rise of "risk" as a challenge has found its repercussion in the "precautionary principle", 304 which is not limited to the environmental law, but finds a parallel, for example, in financial market regulation where "negligence" and the liability have shown to be insufficient for the management of complex risks. This reflexivity of both private and public law beyond the classical limits of "rights", on the one hand, and stable behaviour-oriented norms, on the other, leads to a transformation of normativity in postmodernity. The traditional criteria for the definition of law, as opposed to factual rules, are no longer adequate for the observation of the dynamic of a fragmented selfreflexive legal system that necessarily expands the field of relevance and includes the procedural rules of construction of administrative decisions.

\footnotetext{
${ }^{298}$ Ladeur, supra, note 82.

${ }^{299}$ Urbinati, supra, note 134.

${ }^{300}$ See Karl-Heinz Ladeur, Die Netzwerke des Rechts, 143, in: NETZWERKE IN DER FUNKTIONAL DIFFERENZIERTEN GESELLSCHAFT (Michael Bommes \& Veronika Tacke, eds., 2010).

${ }^{301}$ Farhang, supra, note 297.

302 In my view Sean Farhang, supra, note 297, 45 et seq., overestimates the impact of the specific institutional setting of the US (tension between Congress and the presidential control of administrative agencies in particular. The phenomenon can be observed in other countries with different institutions, as well. It is rather due to the fragmentation of the cognitive basis of society.
}

${ }^{303}$ Kingsbury, supra, note 9 (2009); Teubner, see the references supra, note 23; for a critique (of Kingsbury) See Alexander Somek, The Concept of Law in Global Administrative Law, 20 EUROPEAN JOURNAL OF INTERNATIONAL LAW 985, 986 (2009), who criticizes the theoretical limitations of the New York approach to global administrative law in as much as its focus is on rather broad concepts of "accountability" and not on "legal relationships" and "rights"; see also Armin von Bogdandy, Philipp Dann \& Matthias Goldmann, Developing the Publicness of Public International Law: Towards a Legal Framework of Global Governance Activities, 9 GERMAN LAW JOURNAL 1375 (2008) available at: www.germanlawjournal.com/pdf/Vol09No11/PDF_Vol_09_No_11_13751400_Articles_von\%20Bogdandy_Dann_Goldmann.pdf. - but this is a position which neglects the possibility that the concept of law itself might undergo a process of transformation; for an analysis of the problems with the identification of a "legal source" in postmodernity, see also Zumbansen, supra, note 202,142.

${ }^{304}$ Sadeleer, supra, note 138. 
This development finds a correspondence in the increasing internal fragmentation of the private firm and the decline of the traditional hierarchical "control project", i.e., the rise of heterarchical versions of intra-organisational distribution of competencies. It is reflected in the overarching establishment of public control of the internal processes of knowledge generation within companies. $^{305}$

\section{OUTLOOK}

The paper has tried to show that the evolution of administrative law is characterised by periods of creative construction of new forms, instruments and procedures of administrative law in the administrative decision-making procedures. Court control of these processes should not be interpreted as being the only legal source of administrative law ("judge made law") before the partial codification of general administrative law could be brought about in Europe and the US. If one bears this evolution in mind, it comes as no surprise that the new hybrid postmodern forms of decision-making in both domestic and global public-private networks cannot easily be subsumed under established administrative rules because the experimentation with, and the search for, new forms and procedures of transnational decision-making has not yet come to a conclusion. This constellation is not new in the evolution of administrative law, and it cannot be reduced to the process of globalisation alone: ${ }^{306}$ it is one of the phenomena of the emergence of a new paradigm of (administrative) law: the law of the "network society". ${ }^{307}$

This process demonstrates that also global administrative law cannot be conceived as a mere challenge to the sovereign nation state and the permeability of its territorial borders. Its evolution is a consequence of a deeper transformation of both the economic system and the nation state. As has been demonstrated, the central components of the classical liberal legal system were dependent on stable concepts of property and the territory and their paradigmatic role. The evolution of administration and the economic system is characterised by the rise of the information and of knowledge as the main resource and frame of reference for decisionmaking. The dynamic of the postmodern "knowledge society" is at the bottom of the rapid selftranscendence of the environment of the legal system. Not only the territorial borders of the state, but also the traditional conceptual and institutional separations on which administrative law was founded have been severed.

\footnotetext{
305 See Michael Power, THE AUDIT SOCIETY. RITUALS OF VERIFICATION (1999), who demonstrates also the disfunctionalities of this new approach.

${ }^{306}$ See for the dense relationship between domestic institutions and globalization Jude C. Hays, GLOBALIZATION AND THE NEW POLITICS OF EMBEDDED LIBERALISM 8, 11 (2009).

${ }^{307}$ See Ladeur, supra, note 300, 143.
} 
As a consequence both for the domestic layer of administrative law and the emerging global administrative law, new forms, procedures and meta-rules for an administration beyond the nation state have to be designed. ${ }^{308}$ Considering the dynamic nature of the administration in, and of, networks, more evaluation ${ }^{309}$ ex post and more indirect rule-making will be necessary: "steering" administrative practice ex ante by statutes or by the "application" of informal rules of experience will not be sufficient. The new knowledge base of the "society of networks" will allow for more self-organised rules and patterns, while, at the same time, the decreasing relevance of stable norms in both senses should lead to a focus on procedural norms which are designed with regard to the generation of new knowledge that will be useful for the evaluation ex post.

We are still in the process of experimentation which will generate new forms of action, new procedures, new types of co-ordination between public and private actors. It may well be the case that the role of the judiciary in this new evolutionary process will be negligible, not to mention codification by the legislator. What should be conceivable is a new type of cooperation between domestic agencies and the legislator, with the prospect of coupling transnational procedures of decision-making and domestic legitimation and accountability of decision-makers. ${ }^{310}$ New elements of an inter-twinement of domestic and transnational law might be developing. ${ }^{311}$

308 For the necessity to spread administrative rules in countries of the "Third World" see www.transparency.org./global priorities/aid corruption; Daniel Kaufmann, Aart Kraay \& Massimo Mastruzzi, Measuring Corruption: Myths and Realities, The World Bank Institute. Development Outreach, Januar 2007, www1.worldbank.org/devoutreach; Susan Rose-Ackerman, CORRUPTION AND GOVERNMENT: CAUSES, CONSEQUENCES AND REFORM IX (1999); Migai Akech, Development Partners and Governance of Public Procurement in Kenya: Enhancing Democracy in the Administration of Aid, 37 NEW YORK UNIVERSITY JOURNAL OF INTERNATIONAL LAW AND POLITICS 829 (2006); with a focus on strengthening accountability through administrative law (834).

${ }^{309}$ For a theoretical perspective on "evaluation" as second order knowledge that reuses the same knowledge that has already been referred to in the decision making process Rudolf Stichweh, Wissensgesellschaft und Wissenssystem, 30 SCHWEIZERISCHE ZEITSCHRIFT FÜR SOZIOLOGIE, 147, 155 (2004).

${ }^{310}$ David Dyzenhaus, Accountability and the Concept of (Global) Administrative Law, IILJ Working Paper 2008/7, at http://www.iilj.org/publications/2008-7Dyzenhaus.asp, 13.

${ }^{311}$ For new forms of accountability that emerge at the global level See Helmut Willke, SMART GOVERNANCE: GOVERNING THE GLOBAL KNOWLEDGE SOCIETY 50 (2007). 